\title{
SST phases in the open-ocean and margins of the tropical Pacific; implication on tropical climate dynamics
}

\author{
L.-J. Shiau ${ }^{1}$, S. C. Clemens $^{2}$, M.-T. Chen ${ }^{1}$, M. Yamamoto ${ }^{3}$, and Y. Yokoyama ${ }^{4}$ \\ ${ }^{1}$ Institute of Applied Geosciences, National Taiwan Ocean University, Keelung 20224, Taiwan \\ ${ }^{2}$ Department of Geological Sciences, Brown University, Providence 02912, RI, USA \\ ${ }^{3}$ Faculty of Environmental Earth Science, Hokkaido University, Sapporo 060-0810, Japan \\ ${ }^{4}$ Atmosphere and Ocean Research Institute and Department of Earth and Planetary \\ Sciences, University of Tokyo, Tokyo 113-0033, Japan \\ Received: 28 February 2014 - Accepted: 14 March 2014 - Published: 28 April 2014 \\ Correspondence to: L.-J. Shiau (paleoshiau@gmail.com) \\ Published by Copernicus Publications on behalf of the European Geosciences Union.
}

\section{Implication on tropical climate dynamics}

L.-J. Shiau et al.

\section{Title Page}

\section{Abstract}

Conclusions

Tables

References

Figures

14

4

Back

\section{Full Screen / Esc}

Printer-friendly Version

Interactive Discussion 


\section{Abstract}

The tropical Pacific exerts a major effect on the global climate system and might have driven large extra-tropical climate change. We present a $320 \mathrm{kyr}$ high resolution $\mathrm{U}_{37^{\prime}}^{\mathrm{K}^{\prime}}$-sea surface temperature (SST) record from core MD052928 (11 ${ }^{\circ} 17.26^{\prime} \mathrm{S}$, $5148^{\circ} 51.60^{\prime} \mathrm{E}$, water depth $2250 \mathrm{~m}$ ) located off southeastern Papua New Guinea (PNG), in the western tropical Pacific. The age model of the core is based on AMS ${ }^{14} \mathrm{C}$ dating of planktic foraminifers and correlation of benthic to the LR04 stack. The $\mathrm{U}_{37}^{\mathrm{K}^{\prime}}$-SST ranges from 26.5 to $29^{\circ} \mathrm{C}$, showing glacial-interglacial and millennial variations. We assess the phase of the MD052928 $\mathrm{U}_{37}^{\mathrm{K}^{\prime}}$-SST as part of a synthesis of five other SST

Thecords from the tropical Pacific at the precession, obliquity, and eccentricity bands. The SST records can be separated into two groups when considering SST phase relative to changes in orbital forcing, ice volume and greenhouse gases (GHGs). SST maxima at open-ocean sites within primary equatorial current systems occur between obliquity maxima and methane $\left(\mathrm{CH}_{4}\right)$ maxima but early relative to ice volume minima and $\mathrm{CO}_{2}$ maxima at the obliquity band. In contrast, SST maxima at continental margin sites change are in phase with ice minima and $\mathrm{CO}_{2}$ maxima, likely influenced by the slow response of continental ice sheets and GHGs. At the precession band, the early group located on the Warm Pool area indicates a direct influenced by the local insolation, and with the similar phase progress as the obliquity band. These results indicate that the decreased high-low latitudes insolation gradient and increasing low latitude local insolation resulting in tropical Pacific SST rise. Higher SST would supply more moisture resulting in increased $\mathrm{CH}_{4}$ in the tropical wetlands. This promotes increasing $\mathrm{CO}_{2}$ and deglaciation leading to increase continental and continental margin surface temperatures.

\section{CPD}

10, 1857-1899, 2014

Implication on

tropical climate

dynamics

L.-J. Shiau et al.

\section{Title Page}

Abstract

Introduction

Conclusions

Tables

References

Figures

14

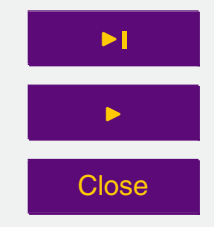

Back

\section{Full Screen / Esc}

Printer-friendly Version

Interactive Discussion 


\section{Introduction}

The tropical Pacific plays an important role in the global climate system. Solar radiation incident on the large area of the equatorial Pacific triggers atmosphere and ocean circulation that results in the transport of heat and moisture from the low to high lati5 tudes (e.g., Hadley Circulation, the Intertropical Convergence Zone (ITCZ) migration, Kuroshio and other currents on the tropical Pacific (Fig. 1a). The trade wind system in tropical Pacific results in stronger wind-driven upwelling and cooler sea surface temperature (SST) $\left(<26^{\circ} \mathrm{C}\right)$ in the central and eastern equatorial Pacific (EEP) named the "cold tongue". In the western tropical Pacific, the Western Pacific warm pool (WPWP) around the New Guinea and Maritime Continent areas is characterized by warmer SST $\left(>28^{\circ} \mathrm{C}\right)$. The eastern to western SST gradient in the tropical Pacific drives the longitudinal Walker Circulation associated with El Niño and La Niña events that affect the modern climate deeply. In addition, the western tropical Pacific is also close to the Asian and Australian continent, playing a role in the East Asian-Australian monsoon 15 systems. Based on the large amount ocean research and satellites data, the tropical Pacific is thought to exert a major effect on the global climate system (e.g. Yan et al., 1992). Similarly, modeling investigations also suggest that long-term changes in tropical Pacific SST patterns might have driven large extra-tropical climate change (Pierrehumbert, 2000).

20 A number of tropical Pacific paleo-SST records have been published (e.g. de GaridelThoron et al., 2005; Lea et al., 2000; Liu and Herbert, 2004; Medina-Elizadle and Lea, 2005) (Fig. 1a). Liu and Herbert (2004) studied ODP $846 \mathrm{U}_{37}^{\mathrm{K}^{\prime}}$-SST from the EEP cold tongue, finding a strong obliquity component. On the basis of this and other evidences, they concluded that ODP 846 SST is less affected by local insolation than by high latitude feedbacks. de Garidel-Thoron et al. (2005) studied MD972140 Mg/Ca-SST also finding a strong obliquity signal in the WPWP and that SST is sensitive to solar radiation. Lea (2004) and Medina-Elizadle and Lea (2005) suggested that atmospheric $\mathrm{CO}_{2}$ variability at the orbital time scale drives tropical Pacific SST change to the 100-kyr
CPD

10, 1857-1899, 2014

Implication on

tropical climate dynamics

L.-J. Shiau et al.

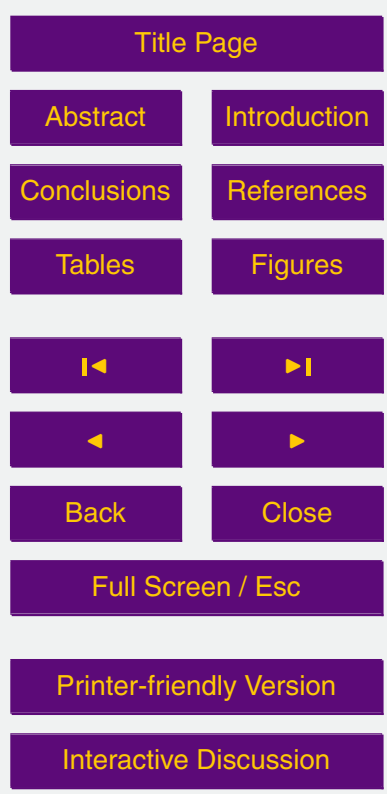


domain after the Middle Pleistocene. Recently, Tachikawa et al. (2009) found that the $\mathrm{CO}_{2}$ rise in Termination I lagged the SST rise in the Southern and tropical Pacific suggesting that early tropical warming could provide heat and moisture to the northern high latitudes and influence the onset of the last deglaciation. Other works suggest that 5 WPWP SST varies similarly to Antarctica temperature changes on the millennial time scale (Rosenthal et al., 2003; Stott et al., 2007) indicating a link to the southern high latitudes through atmosphere or deep water circulation.

In addition to proxy data, there are model studies supporting the idea of a tropical Pacific influence on global climate. Clement et al. (1999) found tropical Pacific SST 10 responses to insolation variability with an obvious precession period as well as ENSOlike variability. Lee and Poulsen (2005) also used a coupled ocean-atmosphere model to reveal the influence of obliquity forcing on climate via changes in meridional insolation gradients. FOAM model results also indicate the geographic distributions of phases between surface air temperature and insolation in the tropical Pacific (Kutzbach et al., 15 2008; Chen et al., 2011).

In order to better understand tropical Pacific climate dynamics, we recovered a CALYPSO core from the southeastern offshore of PNG, Northern Coral Sea (Fig. 1a), MD052928 $\left(11^{\circ} 17.26^{\prime} \mathrm{S}, 148^{\circ} 51.60^{\prime} \mathrm{E}, 2250 \mathrm{~m}\right)$. The sediments are mainly composed of a mixture of carbonate and siliciclastic detritus (Beaufort et al., 2005). The site location is affected by two surface currents, the South Equatorial Current (SEC) and Coral Sea Coastal Current (CSCC) (Wolanski et al., 1995), as well as by Antarctic Intermediate Water (AAIW), Circumpolar Deep Water (CPDW) and Antarctic Bottom Water (AABW) (Bostock et al., 2004; Wyrtki, 1961) connecting the regional oceanography to the southern high latitudes (Fig. 1a). The local climate has two major seasons, the northwestern monsoon during the austral summer and southeastern trades during the austral winter. The PNG area is characterized high annual precipitation, however, higher rainfall in the lowland occurs during the austral summer monsoon period. During El Niño's PNG experiences drought (Ogston et al., 2008).

\section{CPD}

10, 1857-1899, 2014

Implication on

tropical climate dynamics

L.-J. Shiau et al.

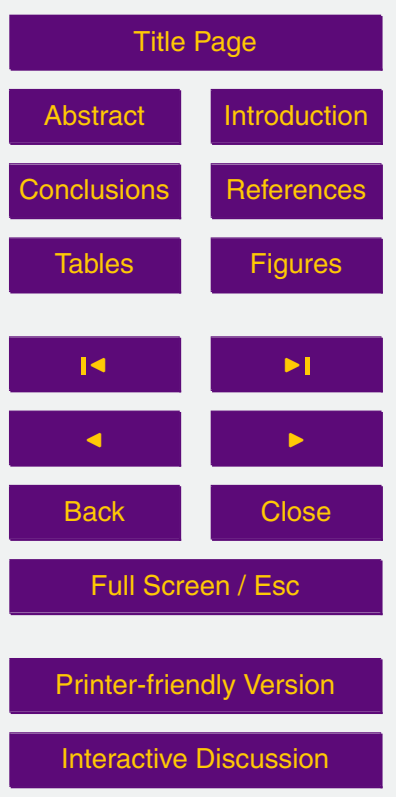


We compare our $320 \mathrm{kyr}$ long high resolution $\mathrm{U}_{37}^{\mathrm{K}^{\prime}}$-SST record from core MD052928, to other SST records from the tropical Pacific including the WPWP, the EEP upwelling area and the South China Sea (SCS) (Fig. 1a). We document the timing of SST from these locations relative to local insolation, Antarctica temperature, and greenhouse 5 gases (GHGs) by using time series methods in order to reveal underlying mechanisms driving surface temperature change.

\section{Methods}

\subsection{Age model}

We used 10 AMS $-{ }^{14} \mathrm{C}$ dates of planktonic foraminifera Globigerinoides ruber and Glo10 bigerinoides sacculifer and compared oxygen isotopes of benthic foraminifera Uvigerina spp. with the LR04 stack (Lisiecki and Raymo, 2005) to establish the age model of core MD052928. The detailed AMS $-{ }^{14} \mathrm{C}$ and oxygen isotope measurements and the age model had been described in Liao (2008) and Shiau et al. (2012).

\section{$2.2 U_{37}^{K^{\prime}}$ paleothermometer}

15 The SST biomarker we used is the alkenone-derived $\mathrm{U}_{37}^{\mathrm{K}^{\prime}}$ index (Prahl and Wakeham, 1987). In this study, we analyzed the whole $24 \mathrm{~m}$ of core MD052928. The top $6 \mathrm{~m}$ was sampled at $5 \mathrm{~cm}$ intervals, below $6 \mathrm{~m}$, we sample at $10 \mathrm{~cm}$ intervals except termination II $(1170-1270 \mathrm{~cm})$ where we sampled at $5 \mathrm{~cm}$ for a total of 300 samples. We calibrated the $\mathrm{U}_{37}^{\mathrm{K}^{\prime}}$-SST by using the nonlinear calibration of Conte et al. (2006) which is based on alkenones from surface water particulates collected from the world ocean, the estimated SST error is $1.2^{\circ} \mathrm{C}$ (Conte et al., 2006). The modern sediment trap observation on the western equatorial Pacific indicates the $\mathrm{C}_{37}$ alkenones flux is with three maxima at February, June, and November (Harada et al., 2001). The mean $\mathrm{U}_{37}^{\mathrm{K}^{\prime}}-\mathrm{SST}$ of core MD052928 (Fig. 2) during the Holocene is about $28.3^{\circ} \mathrm{C}$ that is correspondent to the

CPD

10, 1857-1899, 2014

Implication on

tropical climate

dynamics

L.-J. Shiau et al.

\section{Title Page}

Abstract

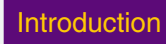

Conclusions

References

Tables

Figures

I

14

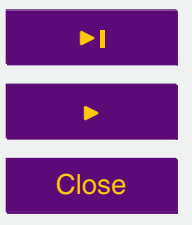

Back

\section{Full Screen / Esc}

Printer-friendly Version

Interactive Discussion 
SST average of these high $\mathrm{C}_{37}$ alkenones flux periods, and close to the modern annual mean SST (Fig. 1). For the analytical procedure, we extracted the lipids with an Accelerated Solvent Extractor (DIONEX ASE 200) using a mixture of dichloromethane: methanol $(6: 4 \mathrm{v} / \mathrm{v})$ at a temperature of $100^{\circ} \mathrm{C}$ and a pressure of $7.6 \times 10^{6} \mathrm{~Pa}$ from the 5 freeze-dried sediment samples. After the extraction, we used silica gel column chromatography to separate alkenones from the extracts. We eluted the alkenones using toluene. Then we analyzed the alkenones by gas chromatography with flame ionization detector. The alkenone analysis procedures are described in Yamamoto et al. (2000).

\section{Results}

\subsection{The SST records of MD052928}

The SST of MD052928 varies between $26.5-29^{\circ} \mathrm{C}$, indicating obvious glacialinterglacial variation (Fig. 2). The warmest periods are the Holocene and MIS 5.5. During these two intervals temperatures exceed the upper limit of the $\mathrm{C}_{37}$ alkenone calibration and are truncated at $28.7^{\circ} \mathrm{C}$ (Conte et al., 2006). Other interglacial periods, such as MIS 5.1, MIS 5.3, MIS 7.1, MIS 7.3, MIS 7.5 and MIS 9, SST are cooler than in the Holocene and MIS 5.5, ranging between 28 and $28.5^{\circ} \mathrm{C}$.

During the glacial periods, the coldest SST occurred at the LGM (19-23 kyrBP) and MIS $8.2(\sim 260 \mathrm{kyrBP})$, the lowest SST is $\sim 26.5^{\circ} \mathrm{C}$. Within other glacial periods and some cold stages in interglacials (e.g. MIS 7.4) the SST is between 27 and $28^{\circ} \mathrm{C}$ except for MIS 6.5 and MIS 8.5 that exceed $28^{\circ} \mathrm{C}$ and are warmer than other glacials. We also note that SST changes lead ice volume at the three terminations, especially at Termination II where the SST leads by $\sim 4$ kyr. These SST findings are consistent with other tropical Pacific records (Fig. 3). In addition, the SST of core MD052928 shows an obvious 23-kyr period.

\section{CPD}

10, 1857-1899, 2014

Implication on

tropical climate

dynamics

L.-J. Shiau et al.

\section{Title Page}

Abstract

Introduction

Conclusions

Tables

References

Figures

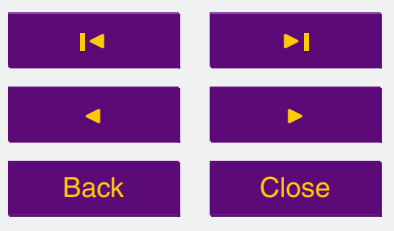

Full Screen / Esc

Printer-friendly Version

Interactive Discussion 


\subsection{Comparison of SST records across the tropical Pacific}

In this study, we compare the MD052928 SST record with other SST records from the tropical Pacific region (Fig. 1a). The modern annual SST cycles for these sites are shown in Fig. 1b. Seasonal amplitudes are small for sites in the core of the warm pool 5 and larger for cold tongue and continental margin sites. Two sites stand out with regard to seasonal amplitude. ODP 1146 has a $6^{\circ} \mathrm{C}$ seasonal amplitude driven by cold winter monsoon winds off the Asian continent. ODP 846 has a $6^{\circ} \mathrm{C}$ amplitude driven by seasonally strengthened upwelling during the prevalent SE trade period at boreal summer in the EEP cold tongue. These modern seasonal amplitudes carry through the paleo 10 record, with ODP 1146 and ODP 846 having the highest amplitude SST records over the past $320 \mathrm{kyr}$ (Fig. 3). Prior to intercomparisons of SST records, we have assessed the various age models in order to compare them with confidence. Where available, we prefer to use age models constructed on the basis of benthic foraminiferal oxygen isotopes because it is less affected by surface hydrologic conditions. The age models of ODP 846 (Liu and Herbert, 2004) and ODP 1146 (Clemens et al., 2008) were constructed using benthic oxygen isotopes. However, ODP 806 (Medina-Elizalde and Lea, 2005) used planktic oxygen isotopes. In this case, we used the age model of Bickert et al. (1993) which is based on the benthic oxygen isotopes although cross spectral comparison of the benthic and planktic-based age models in this case indicates negligible phase differences. MD972140 and MD972142 have no benthic oxygen isotope records; for these cores we use the planktic records.

SST time-series comparisons are illustrated in Fig. 3. Glacial-interglacial SSTs variations are $2-3^{\circ} \mathrm{C}$ with the exception of sites ODP 1146, ODP 846, and MD972142 which have ranges of $\sim 4^{\circ} \mathrm{C}$. All these three records show larger modern seasonal temper25 ature ranges as well (Fig. 1b). On this basis, one might interpret low temperatures at SCS sites ODP 1146 and MD972142 as reflecting colder winter monsoon seasons. Low temperatures at ODP 846 are interpreted as reflecting increased upwelling resulted from the shoaling of the Equatorial Undercurrent (EUC) and the advection of

\section{CPD}

10, 1857-1899, 2014

Implication on

tropical climate dynamics

L.-J. Shiau et al.

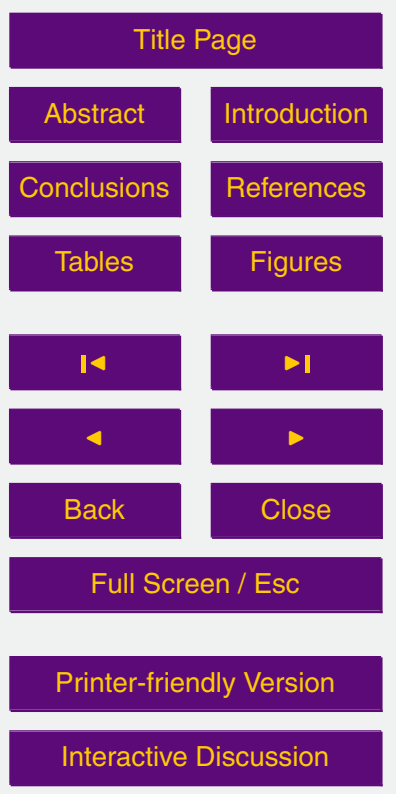


cold water from the Peru-Chile margin during the SE trade prevails at the boreal summer (Liu and Herbert, 2004). Comparing SSTs variations on the terminations, we find that the SCS SST rises concurrently with the ice volume decrease derived from the $\delta^{18} \mathrm{O}$. At other sites, SSTs increase leads ice volume terminations, especially at termi5 nation II. In addition, we did cross-spectral analysis of SST relative to orbital eccentricity (100-kyr), obliquity (41-kyr), and precession (23-kyr) (ETP) (Fig. 4 and Fig. 5). All spectra indicate the strongest concentration of variance at the eccentricity band indicating a strong link between equatorial SST and high latitude ice volume. All records indicate statistically significant coherence $(>80 \%)$ with all orbital parameters (ETP) with the exception of MD972140 at the obliquity band and ODP 846 at the precession band.

In order to discuss the phases of tropical Pacific SSTs we plot all results reactive to $\delta^{18} \mathrm{O}$ from the same core, assigning $\delta^{18} \mathrm{O}$ to the SPECMAP (Imbrie et al., 1984) phases reactive to ETP. Details are described in the Supplement. Briefly, we applied the cross correlation function to adjust the lags of $\delta^{18} \mathrm{O}$ records in order to get better 15 correlation to SPECMAP. After this adjustment, these six $\delta^{18} \mathrm{O}$ records are in phase with SPECMAP on the three orbital bands suggesting we have a reference time frame to compare tropical Pacific SST phases on the orbital time scale. These phase results are summarized and shown in the Supplement, Table 1, and illustrated in Fig. 5.

The SST records can be separated into two groups when considering SST phase 20 relative to changes in orbital forcing, ice volume, air temperature and GHGs recorded in the Antarctica ice core (Fig. 5a-c). SST maxima at open-ocean sites within primary equatorial current systems (MD972140, ODP 806 and ODP 846) slightly lag obliquity maxima, and leading $\mathrm{CH}_{4}$ maxima and ice volume minima at the obliquity band. These sites lead ice volume minima and $\mathrm{CH}_{4}$ maximum at the eccentricity band as well. In contrast, SST maxima at sites proximal to land masses (ODP 1146, MD972142, and MD052928) are in phase with ice minima at the eccentricity and obliquity bands, indirectly influenced by the slow response of continental ice sheets (Supplement Fig. S6a and b). At the precession band ODP 806, and MD052928 SST maxima slightly lag precession minima and are in phase with $\mathrm{CH}_{4}$ maxima. All others are in phase with

\section{CPD}

10, 1857-1899, 2014

Implication on

tropical climate dynamics

L.-J. Shiau et al.

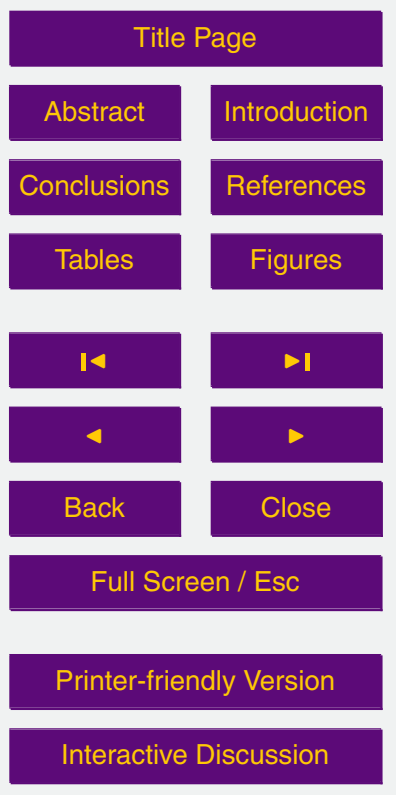

1864 
or slightly lag ice volume minima (Supplement Fig. S6c). We interpret these phase relationships in Sect. 4.2.

\subsection{The comparison of tropical Pacific SSTs to GHGs and Antarctica temperature}

5 GHGs are be distributed globally in a short time and can be use to correlate the age of ice cores between the Northern and Southern Hemisphere (EPICA community members, 2004) and may act as a trigger mechanism of tropical SST (Lea, 2004). In addition, previous studies indicate the Antarctica temperature variability affects the tropical Pacific SST variability by AAIW or sub-Antarctic Mode water indicating the connec10 tion between tropical Pacific and Antarctica climate changes (Toggweiler et al., 1991; Stott et al., 2007; Tachikawa et al., 2009). These indicate a clear relationship among GHGs, southern high latitude temperature and tropical Pacific SST. In this study, we also compare tropical Pacific SSTs to the $\mathrm{CH}_{4}$ concentration (Loulergue et al., 2008) and deuterium record ( $\delta \mathrm{D}$, Antarctica temperature proxy) (Jouzel et al., 2007) from EPICA Dome C using the EDC3 age model (Parrenin et al., 2007) as well as a composite $\mathrm{CO}_{2}$ record from Antarctica ice cores which is also based on the EDC3 age model (Lüthi et al., 2008).

Figure 3 also illustrates the comparison among GHGs, $\delta$ D and tropical Pacific SSTs. Both $\mathrm{CO}_{2}$ and $\mathrm{CH}_{4}$ show higher concentration in interglacials, but there are some dif-

ferences between these two GHGs. For instances, higher $\mathrm{CO}_{2}$ concentration extends from MIS 5.5 to MIS 5.4, but $\mathrm{CH}_{4}$ decreased rapidly after MIS 5.5. $\mathrm{CH}_{4}$ also indicates an abrupt change around the Younger Dryas whereas $\mathrm{CO}_{2}$ does not. Open ocean cores ODP 846, ODP 806 and MD972140 as well as MD052928, indicate slight leads or in-phase relationships between SST and GHGs at terminations whereas those in 25 the SCS clearly lag.

Cross-spectral results show that $\mathrm{CH}_{4}$ is in phase with or slightly lags the earlyresponse SST records and clearly leads the late response records (Fig. 5a-c). Among the $\mathrm{CH}_{4}, \mathrm{CO}_{2}$ and $\delta \mathrm{D}, \mathrm{CH}_{4}$ reaches the maxima prior to $\delta \mathrm{D}$ and $\mathrm{CO}_{2}$ at obliquity and
CPD

10, 1857-1899, 2014

Implication on

tropical climate

dynamics

L.-J. Shiau et al.

\section{Title Page}

Abstract

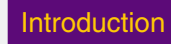

Conclusions

References

Tables

Figures

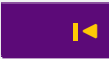

4

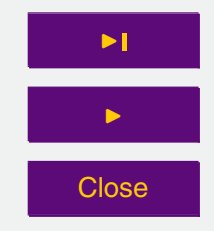

Full Screen / Esc

Printer-friendly Version

Interactive Discussion 
precession bands. $\mathrm{CH}_{4}$ and $\delta \mathrm{D}$ lead ice volume minima at all orbital bands. At the obliquity band, $\mathrm{CH}_{4}$ and $\delta \mathrm{D}$ lag SSTs from the open ocean and lead $\mathrm{CO}_{2}$ and SSTs in the SCS and Coral Sea. At the eccentricity band, GHGs maxima fall between SST maxima of the early and late response groups. At the precession band, $\mathrm{CH}_{4}$ is in phase with 5 the early group SSTs and leads $\delta \mathrm{D}, \mathrm{CO}_{2}$ and the late SST group (Fig. 5). The phase estimations of GHGs and $\delta \mathrm{D}$ are showed in Table 1.

\section{Discussion}

\subsection{SST variability of the tropical Pacific}

The SST variability of the tropical Pacific on annual and orbital time scales is strongly 10 linked to geographic location. MD052928 located off PNG, on the southern margin of the WPWP, has a seasonal SST variation of $\sim 3^{\circ} \mathrm{C}$ which is associated with seasonal meridional solar insolation. During the austral summer, the local SST reaches $29^{\circ} \mathrm{C}$ due to the WPWP southward expansion. In contrast, the SST decreases to $26^{\circ} \mathrm{C}$ when the WPWP contracts northward during the austral winter (Fig. 1b). The SST range at MD052928 on glacial-interglacial time scales is $\sim 1.5-2.5^{\circ} \mathrm{C}$ (Fig. 2). This range is larger than that estimated by $\mathrm{U}_{37}^{\mathrm{K}^{\prime}}$ method for the central WPWP region which indicates $\sim 1^{\circ} \mathrm{C}$ variation during glacial-interglacial cycles (McClymont and Rosell-Melé, 2005; Ohkouchi et al., 1994). Thus, MD052928 is ideally located to monitor changes in the meridional extent of the WPWP on orbital time scales. In addition, we find the $\mathrm{U}_{37^{-}}^{\mathrm{K}^{\prime}}$ SST of core MD052928 rose earlier than ice volume change during Terminations II and III, leading ice volume changes by $\sim 4$ kyrs. The early warming of SST indicates that ice volume change may not the major factor controlling the SST of the southern margin of the WPWP. At termination I, SST and ice volume are closer to being in phase, as reflected in Fig. 5b where the eccentricity phase wheel represents the phase

\section{CPD}

10, 1857-1899, 2014

Implication on

tropical climate

dynamics

L.-J. Shiau et al.

\section{Title Page}

Abstract

Introduction

Conclusions

Tables

References

Figures

14

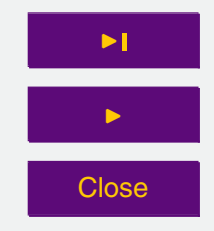

Back

\section{Full Screen / Esc}

Printer-friendly Version

Interactive Discussion 
Furthermore, we found our downcore $\mathrm{U}_{37}^{\mathrm{K}^{\prime}}$-SST record shows an obvious signal at the 23-kyr period but weak at 41-kyr (Fig. 4f). We will discuss this further in Sect. 4.2.

Comparing MD052928 SST to local insolation indicates a strong correlation to June insolation in the Southern Hemisphere (SH), especially at the 23-kyr period (Fig. 6).

5 This result indicates MD052928 SST on the orbital time scale is associated with austral winter insolation when the boreal summer solstice is at the perihelion. These relationships are also illustrated on the precession phase wheel (Supplement Fig. S6c). The central WPWP (ODP 806 and MD972140) is characterized by low amplitude seasonal SST variability (Fig. 1b). However, SST at ODP 806 and MD972140 show a $3^{\circ} \mathrm{C}$ SST decrease at the LGM (Fig. 3) indicating significant WPWP cooling in glacials. The central WPWP may be less affected by land-sea interaction in glacials and likely reflects ocean conditions more directly. The SST differences between glacials and interglacials are lower than in the SCS and eastern Pacific upwelling region. In former studies, using foraminiferal transform functions such as CLIMAP or MARGO, the WPWP area SST decreases $\sim 2{ }^{\circ} \mathrm{C}$ in LGM (CLIMAP, 1981; MARGO Project Members, 2009). Previous $\mathrm{U}_{37}^{\mathrm{K}^{\prime}}$-SSTs studies also indicate $\sim 1^{\circ} \mathrm{C}$ variations during glacial-interglacial cycles in the central WPWP (McClymont and Rosell-Melé, 2005; Ohkouchi et al., 1994; de Garidel-Thoron et al., 2007). These SST differences may result from different proxy responses but not affect the result that SST decreased in glacials. In addition, we note 20 the MD052928 $\mathrm{U}_{37}^{\mathrm{K}^{\prime}}$-SST amplitude is lower than ODP 806 and MD972140 located on the central WPWP (Fig. 3). MD052928 located on the southern Margin of WPWP where should be more sensible to SST variations. Although our observation may be attributed to different proxies; however, some former SST studies in the Coral Sea, such as ODP $820\left(16^{\circ} 38^{\prime} \mathrm{S}, 146^{\circ} 18^{\prime} \mathrm{E}, \mathrm{U}_{37^{\mathrm{K}^{\prime}}} \mathrm{SSST}\right.$ ) (Lawrence and Herbert, 2005), MD972125 $25\left(22^{\circ} 34^{\prime} \mathrm{S}, 161^{\circ} 44^{\prime} \mathrm{E}, \mathrm{U}_{37}^{\mathrm{K}^{\prime}}\right.$ and Mg/Ca-SST) (Tachikawa et al., 2009), and a latitudinal transect along the Coral Sea (foraminiferal transform function) (Anderson et al., 1989) all indicating small glacial-interglacial SST amplitudes similar to MD052928 in
CPD

10, 1857-1899, 2014

Implication on

tropical climate dynamics

L.-J. Shiau et al.

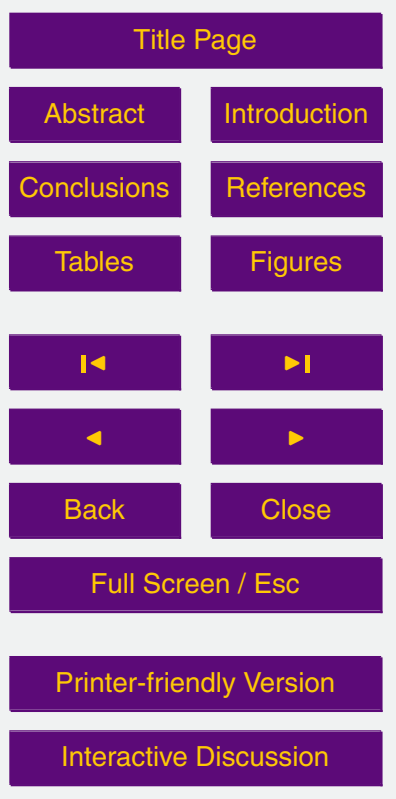

Interactive Discussion 
the North of $\sim 20^{\circ} \mathrm{S}$. This indicates the small SST amplitude may be the local character of the Coral Sea.

The SCS is a marginal sea of the Pacific and its modern annual SST changes are under the influence of the East Asian Monsoon (Wang, 1999). The modern East Asian 5 winter monsoon results in a large north-south SST gradient whereas in summer, East Asian summer monsoon yields a homogenous high SST throughout the whole SCS (Wang, 1999). The seasonal SST variations are $\sim 2^{\circ} \mathrm{C}$ (MD972142, in the southeastern SCS) $\sim 5^{\circ} \mathrm{C}$ (ODP 1146, in the northern SCS) (Fig. 1b) suggesting that paleo variations in SST might be driven by winter dynamics. The glacial-interglacial $\mathrm{U}_{37^{\prime}}^{\mathrm{K}^{\prime}}$-SST 10 variations are $\sim 2-4.5^{\circ} \mathrm{C}$ (Fig. 3). The exposed Sunda Shelf would result in a semiclosed basin that prevented the warm water from the Indo-Pacific warm pool flowing into the SCS, and combine an inflow of cold surface water via the Luzon Strait resulted from the stronger East Asian winter monsoon that results in larger SST decline in glacials (Wang, 1999; Steinke et al., 2008). In addition, we note the SSTs in the SCS 15 are in phase with the oxygen isotope records (Fig. 3) that may indicate the SSTs in the SCS are associated with the ice volume changes, through the strengthened winter monsoon forcing and descending sea level.

ODP 846 is located in the upwelling region of the EEP. The seasonal SST reaches a minimum in boreal summer due to the stronger SE trade resulting in the stronger 20 SEC and EUC as well as increased strength of trade-induced upwelling (Wyrtki, 1981). SST in the east is lower than in the western tropical Pacific and with a larger seasonal SST change (Fig. 1b). The annual SST variation of the EEP is $\sim 6^{\circ} \mathrm{C}$, higher in boreal spring and lower in boreal summer and fall. On the glacial-interglacial time scale, the $\mathrm{U}_{37}^{\mathrm{K}^{\prime}}$-SST of ODP 846 indicates obvious glacial-interglacial variability, and the SST changes between $2.5-4^{\circ} \mathrm{C}$ (Fig. 3). The previous study of Liu and Herbert (2004) indicated the $\mathrm{U}_{37^{\prime}}^{\mathrm{K}^{\prime}}$-SST of ODP 846 is linked to changes in the high northern latitudes and less affected by local insolation. In addition, the cross-spectral results of ODP 846 (Fig. 4g) indicate significant coherency with local insolation at the 41-kyr period but not at the 23-kyr period. This may indicate that the SST in EEP would be attributed to

\section{CPD}

10, 1857-1899, 2014

Implication on

tropical climate dynamics

L.-J. Shiau et al.

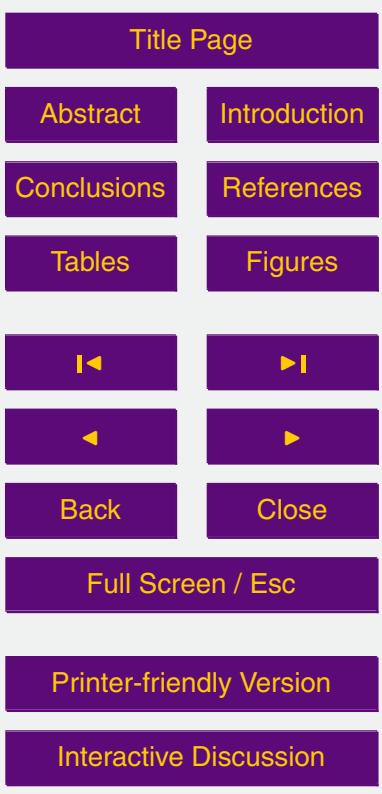

Interactive Discussion 
high latitude feedbacks, either related to atmospheric and oceanic convection or ocean thermohaline circulation (Liu and Herbert, 2004; Martinez-Garcia et al., 2010).

These SST records indicate that SSTs are not simple responses to local insolation but, rather, can be strongly impacted by local geography (such as continental prox5 imity), upwelling, and ocean and atmospheric circulation. Factors leading to the SST phase grouping on the orbital timescale we will discuss in the next section.

\subsection{The mechanisms of phase differences in tropical Pacific SST records}

\subsubsection{Obliquity and eccentricity bands}

At the obliquity and eccentricity bands, two clear groupings exist. Open ocean sites 10 (MD972140, ODP 806, and ODP 846) proximal to the equator (Fig. 4a) comprise a tightly clustered early-response group that slightly lags maximum obliquity and significantly leads $\mathrm{CH}_{4}$ and ice volume minima (Figs. 5a, S6a). Between the latitudes of $\sim 14^{\circ} \mathrm{N}$ and ${ }^{\circ} \mathrm{S}$, increased tilt leads to decreased insolation (Kutzbach et al., 2008). Thus, warm SST at these sites cannot be related to local insolation forcing at the obliq15 uity band.

The early group leads the ice volume change which has been discovered in other studies on the Equatorial pacific (Lea et al., 2000; Liu and Herbert, 2004; de GaridelThoron et al., 2005; Medina-Elizade and Lea, 2005) indicating that ice volume change is not the main factor driving tropical, open ocean SST. ODP 846, ODP 806 and

20 MD972140 show clear power density at the obliquity band as discussed in previous studies (e.g., de Garidel-Thoron et al., 2005; Liu and Herbert, 2004; Medina-Elizade and Lea, 2005). In addition, these three does have an obvious signal and appears in phase relationship at the obliquity band (Fig. S6a, Table S1).

Raymo and Nisancioglu (2003) suggested that the insolation gradient between high 25 and low latitudes is controlled by obliquity forcing; the heat difference between high and low latitudes is driven by obliquity which controls the fluxes of meridional sensible and latent heat transport. We found similar results when comparing MD972140, ODP 806

\section{CPD}

10, 1857-1899, 2014

Implication on

tropical climate

dynamics

L.-J. Shiau et al.

\section{Title Page}

Abstract

Introduction

Conclusions

References

Tables

Figures

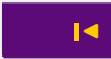

4

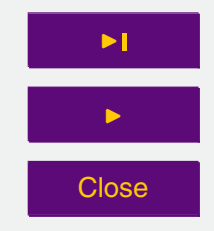

Printer-friendly Version

Interactive Discussion
4

Back

\section{Full Screen / Esc}

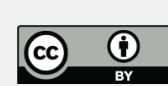


and ODP 846 with the summer half year (21 March to 21 September) insolation gradient between the equator and $65^{\circ} \mathrm{N}$, revealing an in-phase relationship at the obliquity band (Fig. 7). This result suggests the entire tropical Pacific SST at the obliquity band is strongly affected by high-low latitudes heat differences through atmospheric heat 5 transport. In addition, the increasing high-low latitudes insolation gradient could trigger stronger latitudinal atmospheric circulation (e.g. Hadley circulation). Based on Raymo and Nisancioglu's hypothesis, the highest insolation gradient happens when the obliquity reaches a minimum. Our results show the maximum SST of early group is slightly lags obliquity maximum, this may indicate that weaker latitudinal circulation leads to de10 creasing strength of equatorial upwelling system causing the whole equatorial Pacific SST to become warmer.

The late group (MD972142, ODP 1146, and MD052928) comprise sites proximal to land masses and lags the insolation gradient minimum and is in phase with or slightly lags ice volume minimum at the obliquity band (Figs. 5a and 7). The late group, consisting of sites proximal to land, appears to be affected by processes linked to high latitude ice volume. MD972142 and ODP 1146 located in the SCS where is surrounded by the Asian continent, Philippine archipelago, and exposed Sunda Shelf during the glacial that results in a lowstand condition. In glacial periods, the warm water from the Indo-Pacific warm pool could not flow through the exposed Sunda Shelf. In addition, the stronger winter monsoon also results in cooler SST in the SCS during glacial as we discussed in Sect. 4.1. Therefore, SST phases in the SCS might be attributed to the warm water inhibited by the exposed landmass and monsoon system at the obliquity and eccentricity bands. MD052928, located on the northern Coral Sea in which is a relatively opener basin than the SCS. However, MD052928 was close to the exposed

25 Sahul Shelf during the lowstand period. The exposed Sahul Shelf and the New Guinea island might be a barrier to reduce the warm water inflow from the warm pool to Coral Sea during lowstand periods. Thus, MD052928 SST record indicates the in-phase relationship to the ice volume minimum on the obliquity and eccentricity bands (Fig. S6a and b) even through the site does not located on the semi-closed basin like the SCS.

\section{CPD}

10, 1857-1899, 2014

Implication on

tropical climate

dynamics

L.-J. Shiau et al.

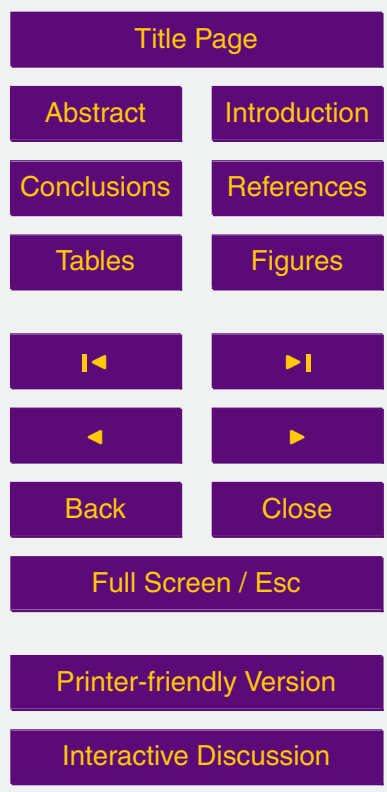

1870 
Furthermore, we also note the late group lags to the $\mathrm{CH}_{4}$, Antarctica $\delta \mathrm{D}$ record, and in phase with the $\mathrm{CO}_{2}$ (Fig. 5a) which may indicate the maximum SSTs of the late group could be related to high latitude forcing. At the obliquity band, the phase relationship among the early and late groups, GHGs and Antarctica $\delta \mathrm{D}$ record may 5 reveal the warmer tropical SST resulting in more $\mathrm{CH}_{4}$ released and the warmer high latitude area, then resulting in the continental ice volume minimum and the rising SSTs proximal to land masses.

Early studies of insolation at the eccentricity band indicate high eccentricity at perihelion results in more heat flux in the tropical latitude due to the effects of the 2 times 10 overhead passages of the sun during each year (Ashkenazy and Gildor, 2008; Berger, 2006; Short et al., 1991). Short et al. (1991) used an energy balance model (EBM) to stimulate the thermal responses of different regions finding the equatorial area has a stronger response at the eccentricity band, whereas the tropical land masses have enhanced thermal responses at all the orbital bands, especially on the eccentricity and 15 precession bands. However, our early group SST phase leads the eccentricity maxima, the orbital configuration might not be the major control factor at this band. Shackleton (2000) studied the phase relationships of deep-Pacific temperature, Antarctica air temperature and $\mathrm{CO}_{2}$ concentration from the Vostok ice core to the ice volume and found the former three proxies all lead the ice volume change and ETP at the eccentricity band. He suggested the eccentricity signal resulted from changes of global carbon cycle caused by the atmospheric $\mathrm{CO}_{2}$ concentration. In recent, a model study also suggests different $\mathrm{CO}_{2}$ concentrations play an important role on the amplification on the eccentricity cycle (Ganopolski and Calvo, 2011). SST phases of early group are in phase with the $\mathrm{CO}_{2}$ concentration at the eccentricity band may support this hypothesis.

25 Nevertheless, we still need longer records and more evidences to discuss the role of the global carbon cycle on the eccentricity band.

The obliquity-band responses of SSTs indicate their phases are associated with the high-low latitudes insolation gradient (Fig. 7). When the gradient reaches a minimum, the weakened equatorial upwelling system resulting in the open-ocean SSTs reach
CPD

10, 1857-1899, 2014

Implication on

tropical climate

dynamics

L.-J. Shiau et al.

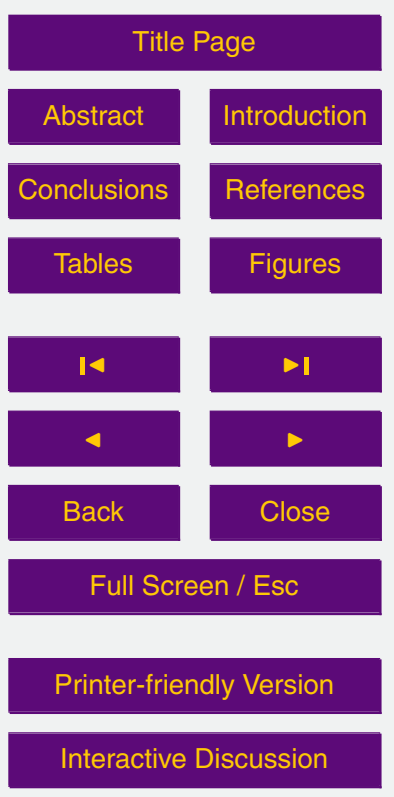

1871 
maxima. Warmer equatorial Pacific SST heads to increased atmospheric moisture and tropical rainfall leading to expand tropical wetlands and increase $\mathrm{CH}_{4}$ production. Increased $\mathrm{CH}_{4}$ promotes increased deglaciation and $\mathrm{CO}_{2}$ leading to increase continental and continental margin surface temperatures. At the eccentricity band, although the 5 SSTs, GHGs and Antarctica $\delta \mathrm{D}$ also indicate similar phase relationship as the obliquity band, however, the phase lead of the early group SSTs is still not well explained.

\subsubsection{Precession band}

At the precession band, all SST records have obvious 23-kyr power (Fig. 4), and the phase can also be separated into 2 groups (Fig. 5c). However, unlike the eccentricity 10 and obliquity bands these groupings do not reflect open-ocean and continental proximity simply. The early group includes MD052928 and ODP 806 located in the WPWP. As in the eccentricity and obliquity bands, the early group slightly leads $\mathrm{CH}_{4}$ and significantly also leads the ice volume minimum. The late group includes MD972142 and ODP 1146 located in the SCS and MD972140 located on the western margin of WPWP.

15 The late group lags ice volume minimum to a slightly greater extent than at obliquity and eccentricity bands. ODP 846 in the EEP has no significant coherence precession band so we don't discuss its phase variation.

The early group phases are close to the boreal summer solstice at the perihelion, when the solar radiation reaches the maximum in the Northern Hemisphere $(\mathrm{NH})$ at the 20 boreal summer (Fig. 6). However, in this case, the phase of the SH site (MD052928) indicates a link to winter dynamics; SST maxima at the time of warmest SH winter. The modern observation indicates the WPWP moves northward and the SST decreases in the MD052928 site during the boreal summer (austral winter). However, our result reveals the SSTs of the early group are in phase with the local insolation during the 25 boreal summer solstice at the perihelion at the precession band indicating the WPWP SSTs are closely linked to the local insolation during this period (Fig. 6). The SSTs of the late group all show very large lags relative to direct local insolation forcing (Fig. 6)

\section{CPD}

10, 1857-1899, 2014

Implication on

tropical climate

dynamics

L.-J. Shiau et al.

\section{Title Page}

Abstract

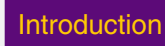

Conclusions

Tables

References

Figures

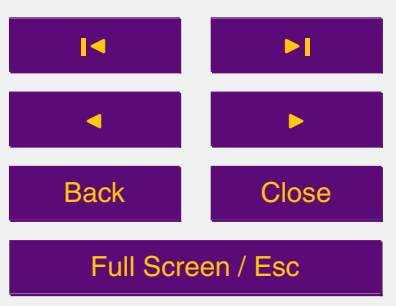

Printer-friendly Version

Interactive Discussion 
indicating there are some internal mechanisms acting on the late group at the precession band.

The late group includes three SST records, MD972142 and ODP 1146 from the SCS and MD972140 from the western part of WPWP. It shows very large lags relative

5 to direct local insolation forcing during the boreal summer and the ice volume minima indicating there are some internal mechanisms acting on the late group at the precession band (Figs. $5 \mathrm{c}$ and 6 ). In addition, the SCS is a relatively closed basin compared to the open ocean and surrounded by the Asian continent and the Philippine and Indonesian archipelagos, and the shallow Sunda Shelf located on the southern SCS.

10 These two records reveal a phase similar to the previous SST records from Asian summer monsoon regions at the precession band (Chen et al., 2003; Clemens and Prell, 2003). We infer that the SCS records may be caused by the timing of increased EASM winds, driving clockwise circulation in the SCS, bringing warm waters to these sites (Wang, 1999). If so, the exposed or submerged Sunda Shelf controlled by the ice vol15 ume change might affect the warm surface water flow into the SCS from the tropical Eastern Indian Ocean and the WPWP during the summer.

MD972140, however, its SST phase lags ODP 806 and MD052928 on the precession band whereas they located on the WPWP region (Supplement Fig. S6c). This might be associated with its location. The New Guinea and Indonesian archipelago are under the Australian monsoon system that is associated with the East Asian Monsoon in the modern world (Suppiah and Wu, 1998). Previous studies also suggested that East Asian-Australian monsoon system influences climate variations on this region at the precession band (e.g. Tachikawa et al., 2011; Shiau et al., 2012). MD972140 located on the western part of WPWP, between the central WPWP and the Asian continent that may be affected by the East Asian-Australian monsoon system. Its phase also indicates slightly lead than sites in the SCS on the precession band (Fig. S6c) that may suggest the influence from the monsoon system except for the local seasonal insolation. Recently, Qu et al. (2005) hypothesized a heat and freshwater conveyor: South China Sea throughflow (SCSTF) based on modern observations and modeling

CPD

10, 1857-1899, 2014

Implication on

tropical climate

dynamics

L.-J. Shiau et al.

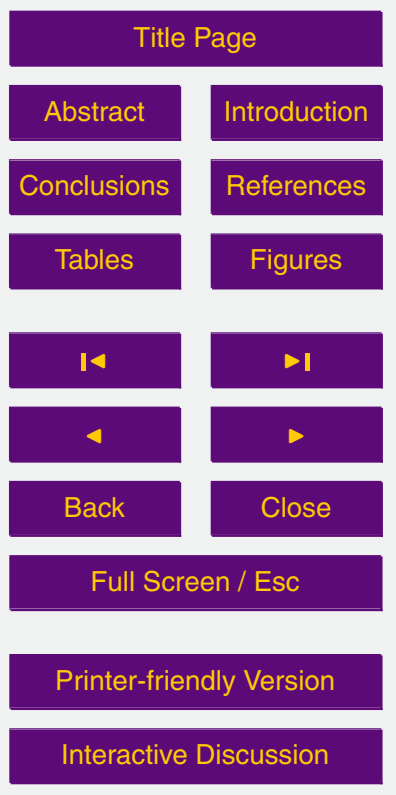

Interactive Discussion 
works. This theory suggests the relatively cold, salty water from the Pacific enters the SCS through the Luzon Strait, through the monsoon and upwelling dynamics to form the warmer and fresher SCSTF in the SCS basin flowing southward then exits the SCS through the Karimata Strait with a shallow water depth $(\sim 40 \mathrm{~m})$ into the Indonesian 5 maritime continent. The SCSTF is suggested as a conveyor belt transferring up to $0.2 \mathrm{PW}$ of heat and $0.1 \mathrm{~Sv}$ of freshwater from the SCS into the Indonesian maritime continent (Qu et al., 2006). The relatively warmer and fresher SCSTF flows into the Makassar Strait and forms a northward surface current then returns into the tropical Pacific (Qu et al., 2005). Furthermore, the model study suggested that the SCSTF 10 would promote the northward heat and water transport in the Makassar Strait during the boreal winter that could enhance the increased SST in the tropical Pacific (Tozuka et al., 2007). MD972140 located on the western WPWP, whereas its SST is in phase with the ice volume minimum and belongs to the late group on the precession band (Fig. S6c) suggesting not only the local seasonal insolation as the early group but also

the interglacial periods. The SCSTF could exit the SCS through the Karimata Strait and flow into the Indonesian maritime continent easily during the highstand condition in interglacials. MD972140 might be under complex interactions of East Asian-Australian monsoon system, local insolation and the SCSTF resulting in its SST phase lag to group are located in the tropics, however, their SSTs are not controlled by the local insolation directly that may be also associated with other internal mechanisms, such as the monsoon, land-sea configuration, and local ocean and atmospheric circulations.

Previous studies indicate significant effects of precession on the tropical climate 25 (Beaufort et al., 2001; Clement et al., 1999; Short and Mengel, 1986). In this study, the early SST group is consistent with this view. The late group, however, responses to the East Asian-Australian monsoon wind patterns. The phase result at the precession band also indicates the influence of the land-sea distribution and local ocean and atmospheric circulations.

\section{CPD}

10, 1857-1899, 2014

Implication on

tropical climate dynamics

L.-J. Shiau et al.

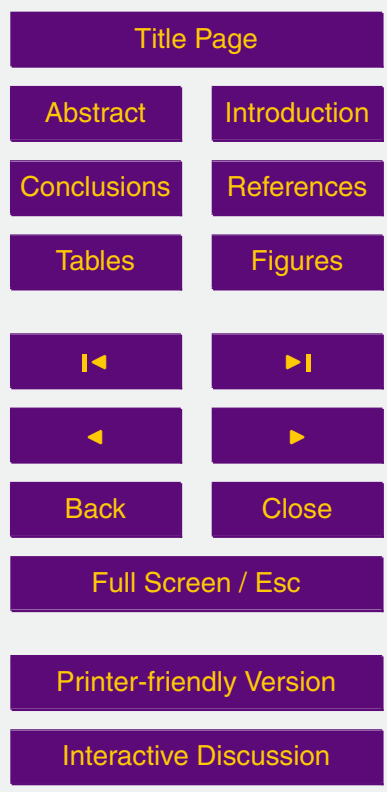


At the precession band, SSTs, GHGs and $\delta \mathrm{D}$ show the similar phase relationship as the obliquity band (Fig. 5a and c) and indicate the same scenario as the obliquity band. Higher local insolation leads the warmer WPWP resulting in higher moisture supply and stronger tropical rainfall and the expansion of tropical wetlands. Then increased $\mathrm{CH}_{4}$

5 production promotes increased deglaciation and $\mathrm{CO}_{2}$ leading to increased continental and continental margin surface temperatures. The difference is that the early group SSTs is associated with the local insolation during the boreal summer directly and distributed on the WPWP, which show the WPWP may play an important role on the global climate system at the precession band.

\subsection{Phase relationships among tropical Pacific SST variability, GHGs, and Antarctic temperature on the orbital time scale}

$\mathrm{CH}_{4}$ shows an earlier phase relative to $\mathrm{CO}_{2}$ at the obliquity and precession bands, and a lag relative to the early group. $\mathrm{CH}_{4}$ is a stronger GHGs with the second radiative forcing after $\mathrm{CO}_{2}$ (Forster et al., 2007) and has a variety of high- and low-latitude wet15 lands and animals sources (Chappellaz et al., 1993a), marine clathrates (Kennett et al., 2000), and thermokarst lakes (Walter et al., 2007) in nature and other anthropogenic sources (e.g. enhanced biomass burning, and rice agriculture) (Forster et al., 2007). Chappellaz et al. (1993a) estimated the annual atmospheric $\mathrm{CH}_{4}$ nature budgets in the LGM and pre-industrial Holocene are 120 and $180 \mathrm{Tgyr}^{-1}$, respectively, which indicates that the difference of atmospheric $\mathrm{CH}_{4}$ between LGM and pre-industrial Holocene is mostly contributed by the expanded wetlands in tropical and $\mathrm{NH}$ high latitude. Evidence from measuring $\delta \mathrm{D}$ of $\mathrm{CH}_{4}$ (Sower, 2006) and cosmogenic ${ }^{14} \mathrm{C}_{\text {of }} \mathrm{CH}_{4}$ (Petrenko et al., 2009,2013 ) in ice cores suggest that the marine clathrate is not a major driver for the abrupt climate change such as Younger Dryas or Heinrich events. The rising sea level also results in some wetlands on the shelf in deglacials. The original vegetation on the shelf buried and decomposed in the wetland when the sea rise in deglacials that could also contributes a part of $\mathrm{CH}_{4}$ into atmosphere (Ridgwell et al., 2012). These results suggest the expanded wetlands are the major source of $\mathrm{CH}_{4}$ since the last glacial. In

CPD

10, 1857-1899, 2014

Implication on

tropical climate dynamics

L.-J. Shiau et al.

\section{Title Page}
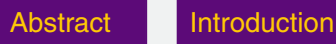

Conclusions

Tables

References

Figures

14 $>1$

4

Back

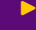

Close

\section{Full Screen / Esc}

Printer-friendly Version

Interactive Discussion

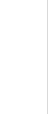

.

.


addition, one of the major atmospheric $\mathrm{CH}_{4}$ sinks is through the oxidation in the troposphere by reaction with hydroxyl radicals (Forster et al., 2007), which appears to bring minimal effects on the variations of $\mathrm{CH}_{4}$ concentration in the glacial-interglacial cycles (Chappellaz et al., 1993a; Thompson et al., 1993, and Singarayer et al., 2011).

5 In this research, phases of tropical SSTs maxima all lead the $\mathrm{CH}_{4}$ maxima at the three orbital bands (Fig. 5). Higher tropical SST could result in more evaporation over the tropical ocean that may induce more rainfall on the tropical land and expanded wetlands. Chappellaz et al. (1993b) suggested the low latitude moisture fluctuations may play an important role in changes of atmospheric $\mathrm{CH}_{4}$ during the deglaciation. From the $10 \mathrm{LGM}$ to the pre-industrial Holocene, the variation of annual $\mathrm{CH}_{4}$ emission flux change is $60 \mathrm{Tg} \mathrm{yr}^{-1}$. Approximately $50 \%$ of the $\mathrm{CH}_{4}$ emission flux was contributed from the tropics and the remaining were mainly sourced from wetlands in boreal high latitudes (Chappellaz et al., 1993a). Loulergue et al. (2008) studied the $\mathrm{CH}_{4}$ in the Dome $\mathrm{C}$ ice core and found the strength of tropical $\mathrm{CH}_{4}$ budgets influenced by monsoon sys15 tems and with an additional source input during major terminations as the retreat of the northern ice sheet allowed higher $\mathrm{CH}_{4}$ emissions from boreal periglacial wetlands. Guo et al. (2012) analyzed the Dome $\mathrm{C} \mathrm{CH}_{4}$ concentration and Chinese loess weathering data pointing out the global monsoon changes have been a constant driver of atmospheric $\mathrm{CH}_{4}$, and the tropical insolation play an important role, especially on the 20 precession and semi-precession bands. Recently, a model study suggested the rising atmospheric $\mathrm{CH}_{4}$ concentration during the Holocene and the end of the last interglacial period is associated with the enhanced precipitation and expanded wetlands in the tropics linked to the nature changes in the Earth's orbital configuration, especially on the precession band (Singarayer et al., 2011). In this scenario, the increasing tropical insolation and warmer tropical SST would lead to variations in the hydrological cycles at low latitudes enhancing $\mathrm{CH}_{4}$ emissions. The phase relationship of the early group SSTs and $\mathrm{CH}_{4}$ maxima at the precession band shown in this study (Fig. $5 \mathrm{c}$ ) supports these model results. On the obliquity band, however, the $\mathrm{CH}_{4}$ maximum slightly lags the early group SST by $\sim 3 \mathrm{kyr}$ (Fig. 5a, Table 1). The warmest equatorial SSTs could

\section{CPD}

10, 1857-1899, 2014

Implication on

tropical climate dynamics

L.-J. Shiau et al.

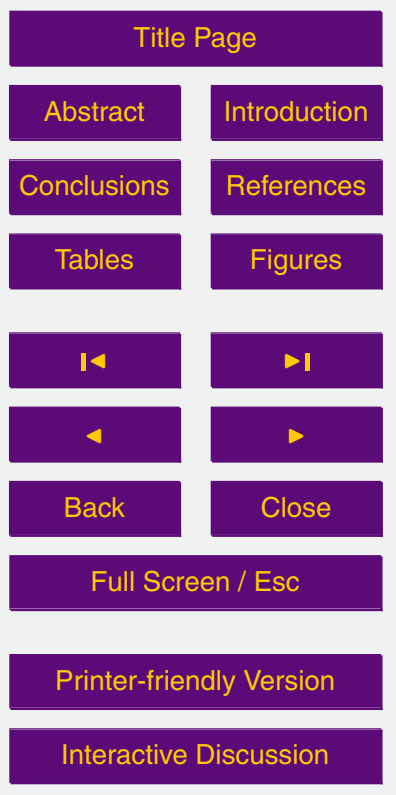


supply more moisture on the tropical land that might enhance the precipitation over the tropical lands and tropical wetland expansion in this band. In addition, the obliquity maximum could result in warmer climate in the high latitudes, especially on the $\mathrm{NH}$. The warmer climate on the northern high latitudes would result in ice melting and more 5 wetland that also promotes $\mathrm{CH}_{4}$ production. On the eccentricity band, the early group of SSTs is also in phase with $\mathrm{CH}_{4}$ maxima (Fig. 5b), however, the SSTs lead the eccentricity maxima which indicate that other internal forcings, such as the global carbon cycle (Shackleton, 2000) may play important roles at this band. All these observations suggest the early warming of tropical SST resulted from tropical insolation changes 10 is primarily responsible for the expansion of tropical wetlands and therefore the increases of $\mathrm{CH}_{4}$ emission in glacial-interglacial cycles. A modern observation indicates the imhomogenous warming SST over the WPWP results in anomalous meridional circulation induced the rising motion and increasing precipitation trend on tropical SH (Feng et al., 2013). This anomalous ascending south of the equator is due to the larger warming trend of WPWP SST in the SH. In our SST records, MD052928 and ODP 806 located on the tropical SH and equator, respectively, slightly leading MD972140 located on the north of equator during the deglaciation (Fig. 3), which might result in difference warming trend over the WPWP on the orbital time scale and enhance higher precipitation and $\mathrm{CH}_{4}$ emission in the tropical $\mathrm{SH}$. Furthermore, the WPWP was also close to exposed Sunda and Sahul shelves located on the tropical SH in glacials that could result in the large expanded wetland during glacials to interglacials until the sea level rose to overlap the shelves. Wetlands resulted from gradually flooding on these shelves also enhances a part of atmospheric $\mathrm{CH}_{4}$ besides the more precipitation (Rigdwell et al., 2012). In addition, orbital configurations of obliquity maxima and precession minima

forcing would enhance the ice sheet melting on high latitudes that may result in more periglacial wetlands and more additional $\mathrm{CH}_{4}$ emission, though the lifetime of $\mathrm{CH}_{4}$ in atmosphere is very short ( $12 \mathrm{yr}$ ) (Forster et al., 2007).

The EPICA dome $C \delta D$ variability was associated with the high latitude insolation resulted from obliquity and precession forcings at the orbital time scale (Jouzel et al.,

\section{CPD}

10, 1857-1899, 2014

Implication on

tropical climate dynamics

L.-J. Shiau et al.

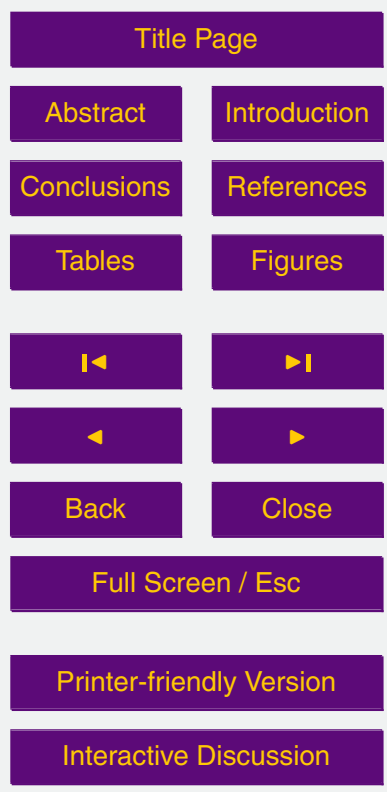


2007). The $\delta$ D variability lags relative to the early SST group at obliquity and precession bands, and is in phase at the eccentricity band (Fig. 5). The early group SSTs lead at obliquity and precession bands indicates that tropical Pacific SSTs of the open ocean and WPWP are not influenced by the southern high latitudes directly as previous stud5 ies (e.g. Stott et al., 2007) but are mainly affected by low latitude insolation forcing. With satellite observation indicating that heat transport in the Pacific is from the low to high latitudes (Hasterath, 1982), this result suggests that the early warming of the tropical Pacific is driven by local insolation changes that lead southern high latitude warming. In addition, the variations of $\delta \mathrm{D}$ in ice cores are in-phase with $\mathrm{CH}_{4}$ at all orbital bands 10 (Fig. 5) that indicate the increases of atmospheric $\mathrm{CH}_{4}$ concentrations provide a positive feedback that contributes the southern high latitudes warming. Thus, the latitudinal heat transport in the Pacific in conjunction with the warming effect from $\mathrm{CH}_{4}$ during the increases of high latitude insolation would result in the warming of southern high latitudes, the retreat of sea ice, and the ice sheet melting on the Antarctica during the 5 deglaciation.

The warming of southern high latitudes results in the melting of sea ice and Antarctica ice sheet that would change the ocean currents around the Antarctic and promote the $\mathrm{CO}_{2}$ rising in atmosphere (Stott et al., 2007). $\mathrm{CO}_{2}$ is a long-lived GHG with strong radiative forcing (Forster et al., 2007). The ocean processes are proposed as the cause of $\mathrm{CO}_{2}$ changes during the glacial-interglacial cycle (Jansen et al., 2007). The ocean is the largest of the relatively fast-exchanging ( $<1 \mathrm{kyr}$ ) carbon reservoir, and the terrestrial change only is not sufficient to explain the low $\mathrm{CO}_{2}$ during glacial (Sigman and Boyle, 2000; Jansen et al., 2007). There are several mechanisms including ocean circulation, marine biological activity, ocean-sediment interactions, seawater carbonate chemistry and air-sea exchange have been proposed to explain the atmospheric $p \mathrm{CO}_{2}$ changes in glacial-interglacial time scales (Jansen et al., 2007). Though all these mechanisms are complicated, the Southern Ocean is thought to be an important driver on glacialinterglacial atmospheric $p \mathrm{CO}_{2}$ changes (Sigman et al., 2010). The change in Southern Ocean circulation results in reducing the water exchange between the Antarctic

\section{CPD}

10, 1857-1899, 2014

Implication on

tropical climate

dynamics

L.-J. Shiau et al.

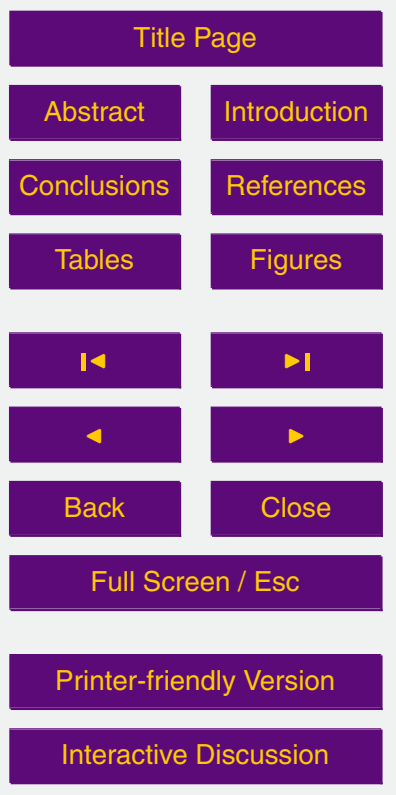


surface water and the underlying deep water that have closed the valve of $\mathrm{CO}_{2}$ releasing to atmosphere during glacials (Sigman et al., 2010). Paleceanographic records (Stott et al., 2007) based on deep-sea temperature suggest that the increase of austral spring insolation would result in the retreat of sea ice and the decrease of stratification

5 by enhanced Ekman transport that would have led to stronger air-sea exchange and rising $\mathrm{CO}_{2}$ during the deglaciation. Opal flux reconstructions in the Southern Ocean (Anderson et al., 2009) also suggest that the strengthened upwelling would enhance the atmospheric $p \mathrm{CO}_{2}$. SST reconstructions of the tropical and southern Pacific show an early warming than the $\mathrm{CO}_{2}$ rise during the Termination I (Tachikawa et al., 2009), 10 providing another support to this mechanism. Other physical parameters may affect the $\mathrm{CO}_{2}$ change during glacial-interglacial cycles. For example, the ocean SST and salinity changes may possibly affect the $p \mathrm{CO}_{2}$ variability during the glacial-interglacial cycle. In a calculation for the $p \mathrm{CO}_{2}$ variability due to the tropical SST and salinity (Sigman and Boyle, 2000), $5{ }^{\circ} \mathrm{C}$ variability in tropical SST and $3 \%$ salinity changes in the ocean 15 during the glacial-interglacial cycle only account for $p \mathrm{CO}_{2}$ variability of $23.5 \mathrm{ppmv}$. in the total glacial-interglacial variation of $\sim 80$ ppmv.

Our results indicate that the $\mathrm{CO}_{2}$ maxima are in-phase with the early group of SSTs at the eccentricity band, but lag to the early group at obliquity and precession bands (Fig. 5). The phase of $\mathrm{CO}_{2}$ maxima at the eccentricity band might reflect the influence of global carbon cycle at eccentricity frequency (Shackleton, 2000) and the effects on tropical SSTs (e.g. Lea, 2004; Medina-Elizadle and Lea, 2005). The early group of tropical Pacific SSTs in phase with Antarctic $\mathrm{CO}_{2}$ at the eccentricity band shown in this study supports the $\mathrm{CO}_{2}$ trigger mechanism at this band (Fig. 5b). On the other hand, the early groups of SSTs lead Antarctic $\mathrm{CO}_{2}$ record at obliquity and precession bands, and the late groups are in phase with $\mathrm{CO}_{2}$ at the obliquity band and lag to $\mathrm{CO}_{2}$ at the precession band (Fig. 5a, c). These indicate that $\mathrm{CO}_{2}$ may not be the major controlling factor on the tropical SST on obliquity and precession cycles. A box core study (ERDC92) of the western equatorial Pacific, which is one of the $\mathrm{CO}_{2}$ source regions during the deglaciation and early Holocene, reveals that the increase of $\mathrm{Mg} / \mathrm{Ca}$ SST leads Boron

\section{CPD}

10, 1857-1899, 2014

Implication on

tropical climate dynamics

L.-J. Shiau et al.

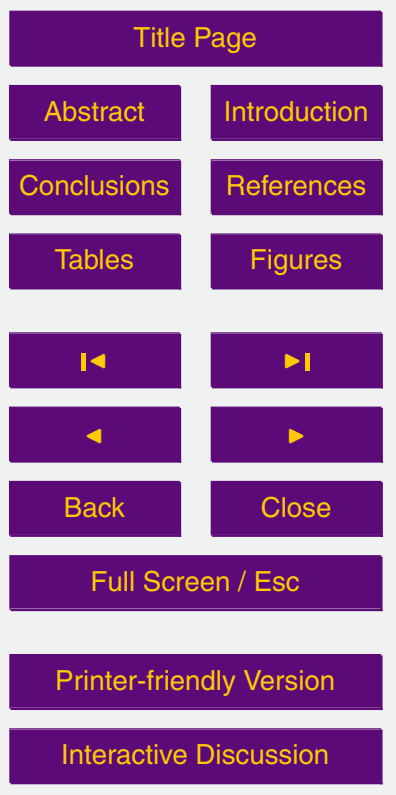

1879 
isotope estimated $p \mathrm{CO}_{2}$ maxima (Palmer and Pearson, 2003). If the early warming on tropical ocean could act efficiently to supply more moisture to make an expansion of tropical wetlands and more $\mathrm{CH}_{4}$ emissions, then the increases of $\mathrm{CH}_{4}$ would accelerate the warming in southern high latitudes and enhance the retreat of sea ice and ice 5 sheet melting in Antarctica. In summary, our phase results of tropical SSTs, $\mathrm{CH}_{4}, \delta \mathrm{D}$ and $\mathrm{CO}_{2}$ reveals the following scenario: the insolation at low latitudes results in the early warming of the tropical open ocean, and then trigger the atmospheric $\mathrm{CH}_{4}$ concentration which in turn forms a positive feedback that may accelerate the deglaciation, then changing the ocean circulation frame in the southern high latitudes and rising of $10 p \mathrm{CO}_{2}$, and the increase of tropical SST in the marginal seas. The GHGs and high latitude warming may not be the major factors controlling the tropical climate. In contrast, the early warming of tropical open ocean and WPWP resulted from the insolation that may play an important role on the deglaciation during the glacial-interglacial cycle.

\section{Conclusions}

15 Core MD052928 from the southern Papua New Guinea provides a high resolution $U_{37^{-}}^{K^{\prime}}$ SST record revealing the variability of the southern WPWP margin and is ideally located to monitor the meridional extent of the WPWP. The downcore $\mathrm{U}_{37}^{\mathrm{K}^{\prime}}$-SST of core MD052928 shows the $\sim 1.5-2.5^{\circ} \mathrm{C}$ variations during the glacial-interglacial variations and an obvious precession period associated to the local austral winter dynamics. 20 However, the lower SST variation amplitude than in the central WPWP that may be attributed to the local character of the Coral Sea.

All tropical Pacific SST records from the three different areas: the WPWP, SCS, and cold tongue in the EEP. Comparisons of the SST records from these three areas indicate that SSTs are not simple responses to their local insolation but, rather can be 25 strongly impacted by local geography, such as continental proximity, upwelling, and ocean and atmospheric circulation.

\section{CPD}

10, 1857-1899, 2014

Implication on

tropical climate

dynamics

L.-J. Shiau et al.

\section{Title Page}

Abstract

Introduction

Conclusions

Tables

References

Figures

14

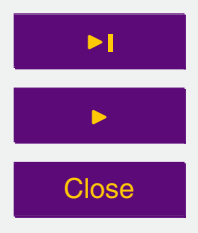

Back

\section{Full Screen / Esc}

Printer-friendly Version

Interactive Discussion 
Cross-Spectral results of tropical Pacific SSTs indicate the SSTs could be separated into two groups at all orbital periods. At the obliquity and eccentricity bands, the early group includes ODP 846, ODP 806 and MD972140 which located on the open ocean and proximal to the equator. The late group consists of ODP 1146, MD972142 and 5 MD052928 which are proximal to the Asian and Australian continents. At the precession band, the two groups are different from the obliquity and eccentricity bands. The early group consists of ODP 806 and MD052928 which located on the WPWP, and the late group includes ODP 1146 and MD972142 located on the SCS and MD972140 located on the western part of WPWP. These results indicate that the changes in high10 low latitudes insolation gradient and tropical local insolation during boreal summer resulting in the warmer SST in the equatorial Pacific and WPWP. Warmer tropical SST leads to more rainfall and the expansion of wetlands in tropical regions resulting in increasing the atmospheric $\mathrm{CH}_{4}$ concentration. Increased $\mathrm{CH}_{4}$ promotes the increased deglaciation and $\mathrm{CO}_{2}$ leading to increased continents and continental margin surface 15 temperatures.

These results suggest the GHGs and early warming in the southern high latitude may be not the major factors controlling the tropical Pacific SSTs variability at the orbital time scale. The tropical climate dynamics in the open ocean is dominated by the low latitude insolation variation, and influences high latitudes through atmosphere and ocean circulations; however, the land-sea distribution, feedbacks of continental ice sheets and GHGs could result in the more complex interactions that may affect the heat transport from the low to high latitudes, and the global climate system.

\section{Supplementary material related to this article is available online at http://www.clim-past-discuss.net/10/1857/2014/cpd-10-1857-2014-supplement.}

\section{CPD}

10, 1857-1899, 2014

Implication on

tropical climate

dynamics

L.-J. Shiau et al.

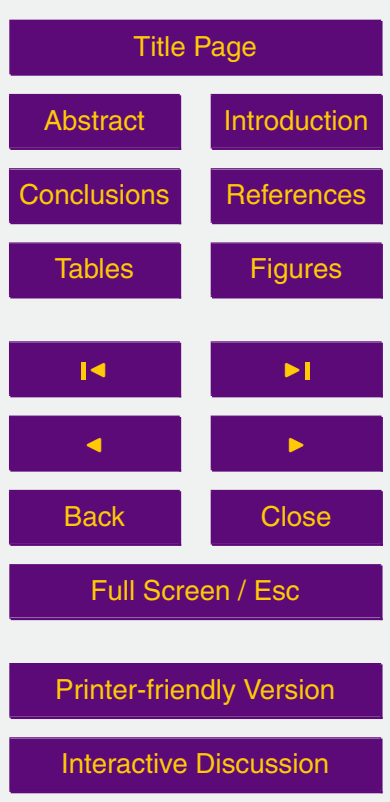

Acknowledgements. We thank N.R. Wan and H. Li in Department of Earth Sciences, National Cheng Kung University helped oxygen isotope data. This research was supported by 
the National Science Council and National Taiwan Ocean University, Republic of China. This study is supported by the grant NSC97-2917-I-019-103 to L.-J. Shiau from the National Science Council, Republic of China.

\section{References}

5 Anderson, D. M., Prell, W. L., and Barratt, N. J.: Estimates of sea surface temperature in the Coral Sea at the last glacial maximum, Paleoceanography, 4, 615-627, 1989.

Anderson, R. F., Ali, S., Bradtmiller, L. I., Nielsen, S. H. H., Fleisher, M. Q., Anderson, B. E., and Burckle, L. H.: Wind-driven upwelling in the Southern Ocean and the deglacial rise in Atmospheric $\mathrm{CO}_{2}$, Science, 323, 1443-1448, 2009.

10 Ashkenazy, Y. and Gildor, H.: Timing and significance of maximum and minimum equatorial insolation, Paleoceanography, 23, PA1206, doi:10.1029/2007PA001436, 2008.

Beaufort, L., de Garidel-Thoron, T., Mix, A. C., and Pisias, N. G.: ENSO-like Forcing on Oceanic Primary Production During the Late Pleistocene, Science, 293, 2440-2444, 2001.

Beaufort, L., Chen, M.-T., Droxler, A. W., Yokoyama, Y., Balut, Y., and Rothe, S.: MD148PECTEN IMAGES XIII Cruise Report, Institut Polaire Francais, Plouzané, 80 pp., 2005.

Berger, A., Loutre, M. F., and Mélice, J. L.: Equatorial insolation: from precession harmonics to eccentricity frequencies, Clim. Past, 2, 131-136, doi:10.5194/cp-2-131-2006, 2006.

Bickert, T., Berger, W. H., Burke, S., Schmidt, H., and Wefer, G.: Late Quaternary stable isotope record of benthic foraminiferas: sites 805 and 806, Ontong Java Plateau, in: Proceedings of the Ocean Drilling Program, Scientific Results, 130, edited by: Berger, W. H., Kroenke, L. W., Janecek, T. R., and Sliter, W. V., College Station, TX, 411-420, 1993.

Bostock, H. C., Opdyke, B. N., Gagan, M. K., and Fifield, L. K.: Carbon isotope evidence for changes in Antarctic Intermediate Water circulation and ocean ventilation in the southwest Pacific during the last deglaciation, Paleoceanography, 19, PA4013, doi:10.1029/2004PA001047, 2004.

Chappellaz, J. A., Fung, I. Y., and Thompson, A. M.: The atmospheric $\mathrm{CH}_{4}$ increase since the Last Glacial Maximum (1). Source estimates. Tellus B, 45, 228-241, 1993a.

Chappellaz, J., Bluniert, T., Raynaud, D., Barnola, J. M., Schwander, J., and Stauffert, B.: Synchronous changes in atmospheric $\mathrm{CH}_{4}$ and Greenland climate between 40 and $8 \mathrm{kyrBP}$, Nature, 366, 443-445, 1993b.

\section{CPD}

10, 1857-1899, 2014

Implication on

tropical climate

dynamics

L.-J. Shiau et al.

\section{Title Page}

Abstract

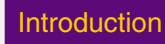

Conclusions

Tables

References

Figures

14

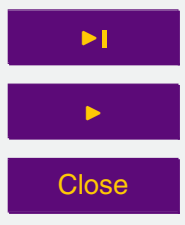

Back

\section{Full Screen / Esc}

Printer-friendly Version

Interactive Discussion 
Chen, G.-S., Liu, Z., Clemens, S. C., Prell, W. L., and Liu, X.: Modeling the time-depended response of Asian Summer Monsoon to obliquity forcing in a coupled GCM: a PHASEMAP sensitivity experiment, Clim. Dynam., 36, 695-710, 2011.

Chen, M.-T., Shiau, L.-J., Yu, P.-S., Chiu, T.-C., Chen, Y.-G., and Wei, K.-Y.: 500000-Year 5 records of carbonate, organic carbon, and foraminiferal sea-surface temperature from the southeastern South China Sea (near Palawan Island), Palaeogeogr. Palaeocl., 197, 113$131,2003$.

Clemens, S. C. and Prell, W. L.: A 350000 year summer-monsoon multi-proxy stack from the Owen Ridge, Northern Arabian Sea, Mar. Geol., 201, 35-51, 2003.

10 Clemens, S. C., Prell, W. L., Sun, Y., Liu, Z., and Chen, G.: Southern Hemisphere forcing of Pliocene $\delta^{18} \mathrm{O}$ and the evolution of Indo-Asian monsoons, Paleoceanography, 23, PA4210, doi:10.1029/2008PA001638, 2008.

Clement, A., Seager, R., and Cane, M. A.: Orbital controls on the El Niño-Southern Oscillation and the tropical climate., Paleoceanography, 14, 441-456, 1999.

CLIMAP Project Members: Seasonal reconstructions of the Earth's surface at the last glacial maximum, Map Chart Series, MC36, Geological Society of America, Boulder, CO, 1981.

Conte, M. H., Sicre, M.-A., Rühlemann, C., Weber, J. C., Schulte, S., Schulz-Bull, D., and Blanz, T.: Global temperature calibration of the alkenone unsaturation index $\left(U_{37}^{K^{\prime}}\right)$ in surface waters and comparison with surface sediments, Geochem. Geophy. Geosy., 7, Q02005, doi:10.1029/2005GC001054, 2006.

de Garidel-Thoron, T., Rosenthal, Y., Bassinot, F., and Beaufort, L.: Stable sea surface temperatures in the west Pacific warm pool over the past 5 million years, Nature, 433, 294-298, 2004.

de Garidel-Thoron, T., Rosenthal, Y., Beaufort, L., Bard, E., Sonzogni, C., and Mix, A. C.: A multiproxy assessment of the western equatorial Pacific hydrography during the last $30 \mathrm{kyr}$, Paleoceanography, 22, PA3204, doi:10.1029/2006PA001269, 2007.

EPICA community members: Eight glacial cycles from an Antarctic ice core, Nature, 429, 623628, 2004.

Feng, J., Li, J., and Xie, F.: Long-term variation of the principal mode of boreal spring hadley circulation linked to SST over the Indo-Pacific warm pool, J. Climate, 26, 532-544, doi:10.1175/jcli-d-12-00066.1, 2013.

Forster, P., Ramaswamy, V., Artaxo, P., Berntsen, T., Betts, R., Fahey, D. W., Haywood, J., Lean, J., Lowe, D. C., Myhre, G., Nganga, J., Prinn, R., Raga, G., Schulz, M., and Van
CPD

10, 1857-1899, 2014

Implication on

tropical climate

dynamics

L.-J. Shiau et al.

\section{Title Page}

Abstract

Introduction

Conclusions

References

Tables

Figures

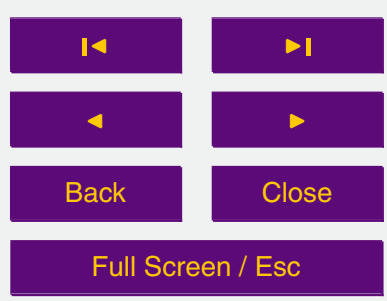

Printer-friendly Version

Interactive Discussion 
Dorland, R.: Changes in atmospheric constituents and in radiative forcing, in: Climate Change 2007: the Physical Science Basis. Contribution of Working Group I to the Fourth Assessment Report of the Intergovernmental Panel on Climate Change, edited by: Solomon, S., Qin, D., Manning, M., Chen, Z., Marquis, M., Averyt, K. B., Tignor, M., and Miller, H. L., Cambridge University Press, Cambridge, UK and New York, NY, USA, 131-234, 2007.

Ganopolski, A. and Calov, R.: The role of orbital forcing, carbon dioxide and regolith in $100 \mathrm{kyr}$ glacial cycles, Clim. Past, 7, 1415-1425, doi:10.5194/cp-7-1415-2011, 2011.

Guo, Z., Zhou, X., and Wu, H.: Glacial-interglacial water cycle, global monsoon and atmospheric methane changes, Clim. Dynam., 39, 1073-1092, doi:10.1007/s00382-011-1147-5, 2012.

Harada, N., Handa, N., Harada, K., and Matsuoka, H.: Alkenones and particulate fluxes in sediment traps from the central equatorial Pacific, Deep-Sea Res. Pt. I, 48, 891-907, 2001.

Hasterath, S.: On meridional heat transports in the world ocean, J. Phys. Oceanogr., 12, 922927, 1982.

Howell, P., Pisias, N., Balance, J., Baughman, J., and Ochs, L.: ARAND Time-Series Analysis Software, Brown University, Providence, RI, 2006.

Imbrie, J., Hays, J. D., Martinson, D. G., McIntyre, A., Mix, A. C., Morley, J. J., Pisias, N. G., Prell, W. L., and Shackleton, N. J.: The orbital theory of Pleistocene climate: support from a revised chronology of the marine $\delta^{18} \mathrm{O}$ record, in: Milankovitch and Climate, Part I, edited by: Berger, A., Imbrie, J., Hays, H., Kukla, G., and Saltzman, B., D. Riedel, Hingham, MA, 269-305, 1984.

Jansen, E., Overpeck, J., Briffa, K. R., Duplessy, J.-C., Joos, F., Masson-Delmotte, V., Olago, D., Otto-Bliesner, B., Peltier, W. R., Rahmstorf, S., Ramesh, R., Raynaud, D., Rind, D., Solomina, O., Villalba, R., and Zhang, D.: Paleocimate, in: Climate Change 2007: the Physical Science Basis. Contribution of Working Group I to the Fourth Assessment Report of the Intergovernmental Panel on Climate Change, edited by: Solomon, S., Qin, D., Manning, M. Chen, Z., Marquis, M., Averyt, K. B., Tignor, M., and Miller, H. L., Cambridge University Press, Cambridge, UK and New York, NY, USA, 433-449, 2007.

Jouzel, J., Masson-Delmotte, V., Cattani, O., Dreyfus, G., Falourd, S., Hoffmann, G., Minster, B., so Nouet, J., Barnola, J. Chappellaz, M., J., Fischer, H., Gallet, J. C., Johnsen, S., Leuenberger, M., Loulergue, L., Luethi, D., Oerter, H., Parrenin, F., Raisbeck, G., Raynaud, D., Schilt, A., Schwander, J., Selmo, E., Souchez, R., Spahni, R., Stauffer, B., Steffensen, J. P.,

\section{CPD}

10, 1857-1899, 2014

Implication on

tropical climate

dynamics

L.-J. Shiau et al.

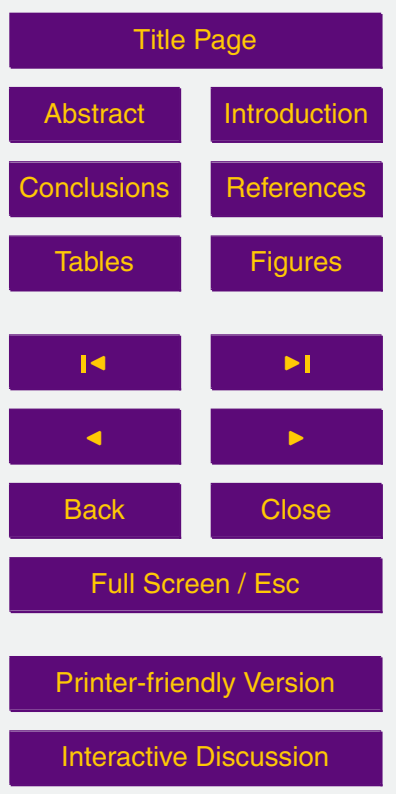


Stenni, B., Stocker, T. F., Tison, J. L., Werner, M., and Wolff, E. W.: Orbital and millennial Antarctic climate variability over the past 800000 years, Science, 317, 793-796, 2007.

Kennett, J. P., Cannariato, K. G., Hendy, I. L., and Behl, R. J.: Carbon isotopic evidence for methane hydrate instability during Quaternary interstadials, Science, 288, 128-133, 2000.

5 Kutzbach, J. E., Liu, X., Liu, Z., and Chen, G.: Simulation of the evolutionary response of global summer monsoons to orbital forcing over the past 280000 years, Clim. Dynam., 30, 567579, 2008.

Laskar, J.: The chaotic motion of the solar system. A numerical estimate of the size of the chaotic zones, Icarus, 88, 266-291, 1990.

10 Lawrence, K. T. and Herbert, T. D.: Late Quaternary sea-surface temperatures in the western Coral Sea: implications for the growth of the Australian Great Barrier Reef, Geology, 33, 677-680, 2006.

Lea, D. W.: The 100000 yr cycle in tropical SST, greenhouse forcing, and climate sensitivity, J. Climate, 17, 2170-2179, 2004.

Lea, D. W., Pak, D. K., and Spero, H. J.: Climate impact of late Quaternary Equatorial Pacific sea surface temperature variations, Science, 289, 1719-1724, 2000.

Lee, S. Y. and Poulsen, C. J.: Tropical Pacific climate response to obliquity forcing in the Pleistocene, Paleoceanography, 20, PA4010, doi:10.1029/2005PA001161, 2005.

Liao, Y.-C.: Benthic foraminifer oxygen isotope stratigraphy of the last 300000 years in core $20 \quad$ MD052928 from offshore southeastern Papua New Guinea, M.S. thesis, National Taiwan Ocean University, 55 pp., 2008.

Lisiecki, L. E. and Raymo, M. E.: A Pliocene-Pleistocene stack of 57 globally distributed benthic $\delta^{18} \mathrm{O}$ records, Paleoceanography, 20, PA1003, doi:10.1029/2004PA001071, 2005.

Liu, Z. and Herbert, T. D.: High-latitude influence on the eastern equatorial Pacific climate in the early Pleistocene epoch, Nature, 427, 720-723, 2004.

Locarnini, R. A., Mishonov, A. V., Antonov, J. I., Boyer, T. P., Garcia, H. E., Baranova, O. K., Zweng, M. M., and Johnson, D. R.: World Ocean Atlas 2009, Volume 1: Temperature, US Gov. Printing Office, Washington, DC, 2010.

Loulergue, L., Schilt, A., Spahni, R., Masson-Delmotte, V., Blunier, T., Lemieux, B., Barnola, J.30 M., Raynaud, D., Stocker, T. F., and Chappellaz, J.: Orbital and millennial-scale features of atmospheric $\mathrm{CH}_{4}$ over the past 800000 years, Nature, 453, 383-386, 2008.

\section{CPD}

10, 1857-1899, 2014

Implication on

tropical climate

dynamics

L.-J. Shiau et al.

\section{Title Page}

Abstract

Introduction

Conclusions

Tables

References

Figures

14

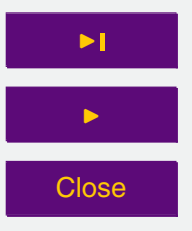

Back

\section{Full Screen / Esc}

Printer-friendly Version

Interactive Discussion 
Lüthi, D., Le Floch, M., Bereiter, B., Blunier, T., Barnola, J.-M., Siegenthaler, U., Raynaud, D., Jouzel, J., Fischer, H., Kawamura, K., and Stocker, T. F.: High-resolution carbon dioxide concentration record 650 000-800 000 years before present, Nature, 453, 379-382, 2008.

MARGO Project Members: Constraints on the magnitude and patterns of ocean cooling at the $5 \quad$ Last Glacial Maximum, Nat. Geosci., 2, 127-132, 2009.

Martínez-Garcia, A., Rosell-Melé, A., McClymont, E. L., Gersonde, R., and Haug, G. H.: Subpolar link to the emergence of the modern equatorial Pacific Cold Tongue, Science, 328, 1550-1553, 2010.

McClymont, E. L. and Rosell-Mele, A.: Links between the onset of modern Walker circulation and the mid-Pleistocene climate transition, Geology, 33, 389-392, 2005.

Medina-Elizalde, M. and Lea, D. W.: The Mid-Pleistocene transition in the Tropical Pacific, Science, 310, 1009-1013, 2005.

Mix, A. C., Le, J., and Shackleton, N. J.: Benthic foraminiferal stable isotope stratigraphy of site 846: 0-1.8 Ma, in: Proceedings of the Ocean Drilling Program, Scientific Results, 138, edited by: Pisias, N. G., Mayer, L. A., Janecek, T. R., Palmer-Julson, A., and van Andel, T. H., College Station TX, 839-854, 1995.

Ogston, A. S., Sternberg, R. W., Nittrouer, C. A., Martin, D. P., Goñi, M. A., and Crockett, J. S.: Sediment delivery from the Fly River tidally dominated delta to the nearshore marine environment and the impact of El Niño, J. Geophys. Res., 113, F01S11, doi:10.1029/2006JF000669, 2008.

Ohkouchi, N., Kawamura, K., Nakamura, T., and Taira, A.: Small changes in the sea surface temperature during the last 20000 years: molecular evidence from the western tropical Pacific, Geophys. Res. Lett., 21, 2207-2210, 1994.

Palmer, M. R. and Pearson, P. N.: A 23000 -year record of surface water $\mathrm{pH}$ and $p \mathrm{CO}_{2}$ in the western equatorial Pacific Ocean, Science, 300, 480-482, 2003.

Parrenin, F., Barnola, J.-M., Beer, J., Blunier, T., Castellano, E., Chappellaz, J., Dreyfus, G., Fischer, H., Fujita, S., Jouzel, J., Kawamura, K., Lemieux-Dudon, B., Loulergue, L., MassonDelmotte, V., Narcisi, B., Petit, J.-R., Raisbeck, G., Raynaud, D., Ruth, U., Schwander, J., Severi, M., Spahni, R., Steffensen, J. P., Svensson, A., Udisti, R., Waelbroeck, C., and Wolff, E.: The EDC3 chronology for the EPICA Dome C ice core, Clim. Past, 3, 485-497, doi:10.5194/cp-3-485-2007, 2007.

Petrenko, V. V., Smith, A. M., Brook, E. J., Lowe, D., Riedel, K., Brailsford, G., Hua, Q., Schaefer, H., Reeh, N., Weiss, R. F., Etheridge, D., and Severinghau, J. P.: ${ }^{14} \mathrm{CH}_{4}$ measurements

\section{CPD}

10, 1857-1899, 2014

Implication on

tropical climate

dynamics

L.-J. Shiau et al.

\section{Title Page}

Abstract

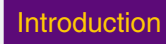

Conclusions

References

Tables

Figures

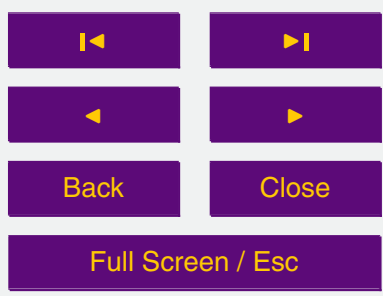

Printer-friendly Version

Interactive Discussion 
in Greenland ice: investigating last glacial termination $\mathrm{CH}_{4}$ sources, Science, $324,506-508$, 2009.

Petrenko, V. V., Severinghaus, J. P., Smith, A. M., Riedel, K., Baggenstos, D., Harth, C., Orsi, A., Hua, Q., Franz, P., Takeshita, Y., Brailsford, G. W., Weiss, R. F., Buizert, C., Dickson, A., and

5 Schaefer, $\mathrm{H}$.: High-precision ${ }^{14} \mathrm{C}$ measurements demonstrate production of in situ cosmogenic ${ }^{14} \mathrm{CH}_{4}$ and rapid loss of in situ cosmogenic ${ }^{14} \mathrm{CO}$ in shallow Greenland firn, Earth Planet. Sc. Lett., 365, 190-197, doi:10.1016/j.epsl.2013.01.032, 2013.

Pierrehumbert, R. T.: Climate change and the tropical Pacific: the sleeping dragon wakes, P. Natl. Acad. Sci. USA, 97, 1355-1358, 2000.

10 Prahl, F. G. and Wakeham, S. G.: Calibration of unsaturation patterns in long-chain ketone compositions for palaeotemperature assessment, Nature, 330, 367-369, 1987.

Qu, T., Du, Y., Meyers, G., Ishida, A., and Wang, D.: Connecting the tropical Pacific with Indian Ocean through South China Sea, Geophys. Res. Lett., 32, L24609, doi:10.1029/2005gl024698, 2005.

Qu, T., Du, Y., and Sasaki, H.: South China Sea throughflow: a heat and freshwater conveyor, Geophys. Res. Lett., 33, L23617, doi:10.1029/2006gl028350, 2006.

Raymo, M. E. and Nisancioglu, K.: The $41 \mathrm{kyr}$ world: Milankovitch's other unsolved mystery, Paleoceanography, 18, 1011, doi:10.1029/2002PA000791, 2003.

Ridgwell, A., Maslin, M., and Kaplan, J. O.: Flooding of the continental shelves as a contributor to deglacial $\mathrm{CH}_{4}$ rise, J. Quaternary Sci., 27, 800-806, doi:10.1002/jqs.2568, 2012.

Rosenthal, Y., Oppo, D. W., and Linsley, B. K.: The amplitude and phasing of climate change during the last deglaciation in th Sulu Sea, western equatorial Pacific, Geophys. Res. Lett., 30, 1428, doi:10.1029/2002GL016612, 2003.

Shackleton, N. J.: Identified and found to lag temperature, carbon dioxide, and orbital eccentricity, Science, 289, 1897-1902, 2000.

Shiau, L.-J., Yu, P.-S., Wei, K.-Y., Yamamoto, M., Lee, T.-Q., Yu, E.-F., Fang, T.-H., and Chen, M.T.: Sea surface temperature, productivity, and perrestrial flux variations of the southeastern South China Sea over the past 800000 years (IMAGESMD972142), Terr. Atmos. Ocean. Sci., 19, 363-376, 2008.

so Shiau, L.-J., Chen, M.-T., Huh, C.-A., Yamamoto, M., and Yokoyama, Y.: Insolation and crosshemispheric controls on Australian monsoon variability over the past $180 \mathrm{ka}$ : new evidence from offshore southeastern Papua New Guinea, J. Quaternary Sci., 27, 911-920, doi:10.1002/jqs.2581, 2012.

CPD

10, 1857-1899, 2014

Implication on

tropical climate

dynamics

L.-J. Shiau et al.

\section{Title Page}

Abstract

Introduction

Conclusions

Tables

References

Figures

14

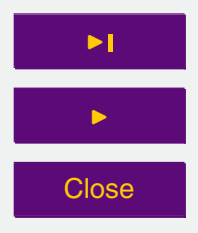

Back

Full Screen / Esc

Printer-friendly Version

Interactive Discussion 
Short, D. A. and Mengel, J. G.: Tropical climatic phase lags and Earth precession cycle, Nature, 323, 48-50, 1986.

Short, D. A., Mengel, J. G., Crowley, T. J., Hyde, W. T., and North, G. R.: Filtering of Milankovitch cycles by earth's geography, Quaternary Res., 35, 157-173, 1991.

5 Sigman, D. M. and Boyle, E. A.: Glacial/interglacial variations in atmospheric carbon dioxide, Nature, 407, 859-869, 2000.

Sigman, D. M., Hain, M. P., and Haug, G. H.: The polar ocean and glacial cycles in atmospheric $\mathrm{CO}_{2}$ concentration, Nature, 466, 47-55, 2010.

Singarayer, J. S., Valdes, P. J., Friedlingstein, P., Nelson, S., and Beerling, D. J.: Late Holocene methane rise caused by orbitally controlled increase in tropical sources, Nature, 470, 82-85, 2011.

Sowers, T.: Late Quaternary atmospheric $\mathrm{CH}_{4}$ isotope record suggests marine clathrates are stable, Science, 311, 838-840, 2006.

Steinke, S., Yu, P.-S., Kucera, M., and Chen, M.-T.: No-analog planktonic foraminiferal faunas in the glacial southern South China Sea: implications for the magnitude of glacial cooling in the western Pacific warm pool, Mar. Micropaleontol., 66, 71-90, 2008.

Stott, L., Timmermann, A., and Thunell, R.: Southern Hemisphere and deep-sea warming led deglacial atmospheric $\mathrm{CO}_{2}$ rise and tropical warming, Science, 318, 435-438, 2007.

Suppiah, R. and Wu. X.: Surges, cross-equatorial flows and their links with the Australian summer monsoon circulation and rainfall, Aust. Meteorol. Mag., 47, 113-130, 1998.

Tachikawa, K., Vidal, L., Sonzogni, C., and Bard, E.: Glacial/interglacial sea surface temperature changes in the Southwest Pacific ocean over the past $360 \mathrm{ka}$, Quaternary Sci. Rev., 28, 1160-1170, 2009.

Tachikawa, K., Cartapanis, O., Vidal, L., Beaufort, L., Barlyaeva, T., and Bard, E.: The precession phase of hydrological variability in the Western Pacific warm pool during the past $400 \mathrm{ka}$, Quaternary Sci. Rev., 30, 3716-3727, doi:10.1016/j.quascirev.2011.09.016, 2011.

Thompson, A. M., Chappellaz, J. A., Fung, I. Y., and Kucsera, T. L.: The atmospheric $\mathrm{CH}_{4}$ increase since the Last Glacial Maximum (2). Interactions with oxidants, Tellus B, 45, 242257, 1993.

so Tomczak, M. and Godfrey, J. S.: Regional Oceanography: an Introduction, 2nd Edn., Daya, Delhi, 2003.

Toggweiler, J. R., Dixon, K., and Broecker, W. C.: The Peru upwelling and the ventilation of the South Pacific thermocline, J. Geophys. Res., 96, 20467-20497, 1991.

CPD

10, 1857-1899, 2014

Implication on

tropical climate

dynamics

L.-J. Shiau et al.

\section{Title Page}

Abstract

Introduction

Conclusions

References

Tables

Figures

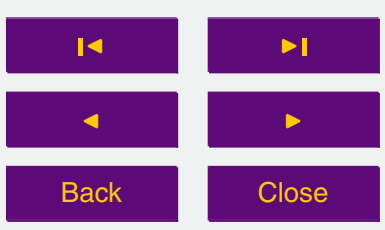

Full Screen / Esc

Printer-friendly Version

Interactive Discussion 
Tozuka, T., Qu, T., and Yamagata, T.: Dramatic impact of the South China Sea on the Indonesian Throughflow, Geophys. Res. Lett., 34, L12612, doi:10.1029/2007gl030420, 2007.

Walter, K. M., Edwards, M. E., Grosse, G., Zimov, S. A., and Chapin III, F. S.: Thermokarst lakes as a source of atmospheric $\mathrm{CH}_{4}$ during the last deglaciation, Science, 318, 633-636, 2007.

5 Wang, P.: Response of Western Pacific marginal seas to glacial cycles: paleoceanographic and sedimentological features, Mar. Geol., 156, 5-39, 1999.

Wolanski, E., Norro, A., and King, B.: Water circulation in the Gulf of Papua, Cont. Shelf Res., 15, 185-212, 1995.

Wyrtki, K.: The flow of Water ionto the deep sea basins of the western south Pacific ocean, Australian J. Mar. Fresh. Res., 12, 1-16, 1961.

Wyrtki, K.: An estimate of equatorial upwelling in the Pacific, J. Phys. Oceanogr., 11, 12051214, 1981.

Yamamoto, M., Yamamuro, M., and Tada, R.: Late Quaternary records of organic carbon, calcium carbonate, and biomarkers from site 1016 off Point Conception, California margin, in: Proceedings of the Ocean Drilling Program, Scientific Results, 67, edited by: Lyle, M., Koizumi, I., Richter, C., Moore Jr., T., College Station TX, 183-194, 2000.

Yan, X.-H., Ho, C.-R., Zheng, Q., and Klemas, V.: Temperature and size variabilities of the Western Pacific warm pool, Science, 258, 1643-1645, 1992.

CPD

10, 1857-1899, 2014

Implication on

tropical climate

dynamics

L.-J. Shiau et al.

Title Page

Abstract

Introduction

Conclusions

References

Tables

Figures

14

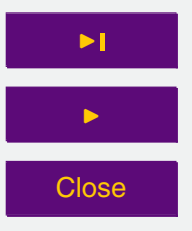

Back

Close

Full Screen / Esc

Printer-friendly Version

Interactive Discussion 
CPD

10, 1857-1899, 2014

Implication on tropical climate dynamics

L.-J. Shiau et al.

\section{Title Page}

Abstract

Introduction

Mean Phases (kyr)

Early Group

Late Group

$5.6 \pm 3.1 \quad-2.7 \pm 1.4 \quad-1.5 \pm 0.8$

Antarctic Ice Core Records (kyr)

EPICA Dome $\mathrm{C} \delta \mathrm{D}$

$$
-3.9 \pm 1.7-9.0 \pm 1.1-6.1 \pm 0.5
$$

EPICA Dome $\mathrm{C} \mathrm{CH}_{4}$

$$
\begin{array}{lll}
6.9 \pm 3.3 & -5.5 \pm 1.5 & -3.5 \pm 0.6 \\
0.3 \pm 3.6 & -5.5 \pm 2.4 & -1.9 \pm 1.0 \\
3.6 \pm 3.6 & -9.3 \pm 2.3 & -4.3 \pm 1.3
\end{array}
$$

* Postive values indicate that parameters lead the orbital forcing; negative values indicate that parameters lag the orbital forcing.
Conclusions

Tables

References

Figures

14

4

Back

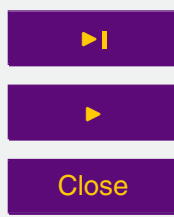

Full Screen / Esc

Printer-friendly Version

Interactive Discussion 
( a)
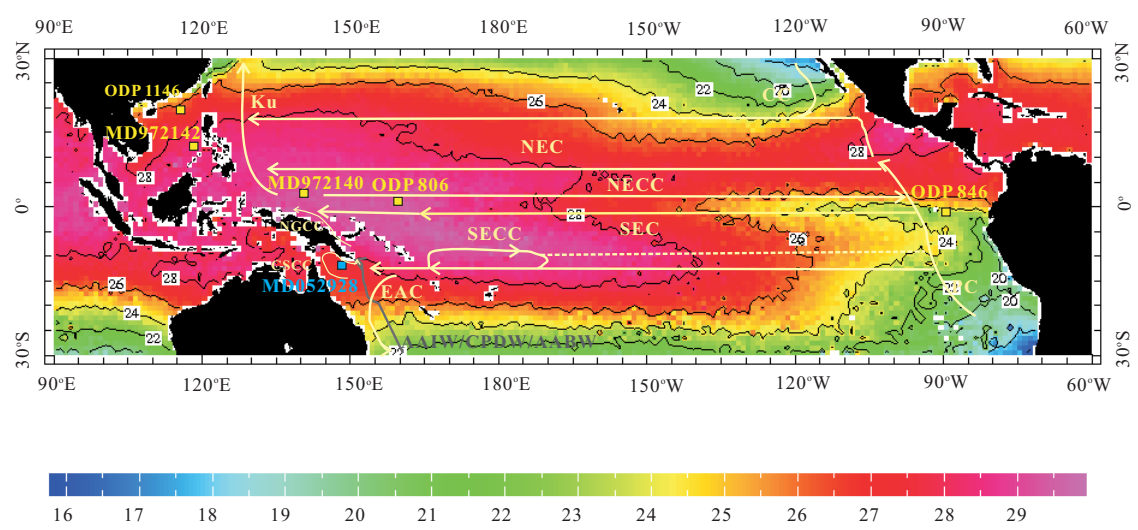

Sea Surface Temperature $\left({ }^{\circ} \mathrm{C}\right)$

(b)

\begin{tabular}{llll|}
$\longleftarrow$ & MD052928 & & MD972140 \\
& ODP 846 & MD972142 \\
ODP 806 & - & ODP 1146 \\
\hline
\end{tabular}

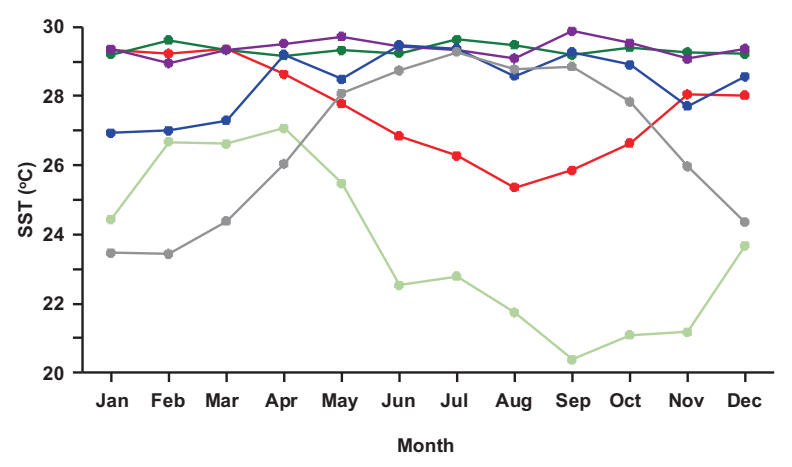

1891

\section{CPD}

10, 1857-1899, 2014

Implication on tropical climate dynamics

L.-J. Shiau et al.

\section{Title Page}

Abstract

Introduction

Conclusions

References

Tables

Figures

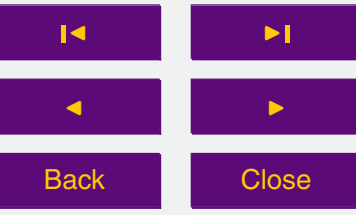

Full Screen / Esc

Printer-friendly Version

Interactive Discussion

(c) (1) 


\section{CPD}

10, 1857-1899, 2014

Implication on

tropical climate dynamics

Fig. 1. (a) The Annual average SST in the tropical Pacific and the sites location in this study. Sites include ODP $806\left(0^{\circ} 19.1^{\prime} \mathrm{N}, 159^{\circ} 21.7^{\prime} \mathrm{E}, 2520 \mathrm{~m} ; \mathrm{Mg} / \mathrm{Ca}\right)$ (Medina-Elizald and Lea, 2005) and MD972140 ( $2^{\circ} 02^{\prime} \mathrm{N}, 141^{\circ} 46^{\prime} \mathrm{E}, 2547 \mathrm{~m} ; \mathrm{Mg} / \mathrm{Ca}$ ) (de Garidel-Thoron et al., 2005) of WPWP, MD972142 (12 $41.133^{\prime} \mathrm{N}, 119^{\circ} 27^{\prime} 90^{\prime} \mathrm{E}, 1557 \mathrm{~m}$; unsaturated alkenones) (Shiau et al., 2008), ODP $1146\left(19^{\circ} 27.40^{\prime} \mathrm{N}, 116^{\circ} 16.37^{\prime} \mathrm{N}, 2.092 \mathrm{~m}\right.$; unsaturated alkenones) (Clemens et al., 2008) of SCS, and ODP $846\left(3^{\circ} 5^{\prime} \mathrm{S}, 90^{\circ} 49^{\prime} \mathrm{E}, 3307 \mathrm{~m}\right.$; unsaturated alkenones) (Liu and Herbert, 2004) of EEP. The SST data are from the WOA09 database (Locarnini et al., 2010) which can be gotten from the website: http://iridl.Ideo.columbia.edu/SOURCES/.NOAA/.NODC/. The blue square indicates the new site, MD052928 in this study. The yellow squares indicate the published sites of the tropical Pacific used in this study. Light yellow lines with arrows indicate the main surface currents of the tropical Pacific included modified from Tomczak and Godfrey (2003). The abbreviations refer to surface currents: Ku: Kuroshio, CC: California Current, NEC: North Equatorial Current, NECC: North Equatorial Counter Current, SEC: South Equatorial Current, SECC: South Equatorial Counter Current, NGCC: New Guinea Coastal Current, CSCC: Coral Sea Coastal Current, EAC: East Australian Current, PC: Peru Current. The dark gray arrow indicates the intermediate and deep water currents after Wyrtki (1961) and Bostock et al. (2004). The abbreviations refer to intermediate and bottom currents: AAIW: Antarctic Intermediate Water, CPDW: Circumpolar Deep Water, AABW: Antarctic Bottom Water. (b) The annual SST variations of sites in this study and are also from the WOA09 database.
L.-J. Shiau et al.

\section{Title Page}

Abstract Introduction

Conclusions

Tables

References

Figures

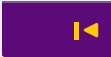

14

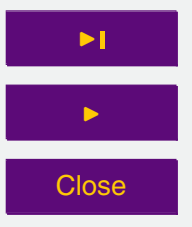

Back

\section{Full Screen / Esc}

Printer-friendly Version

Interactive Discussion 


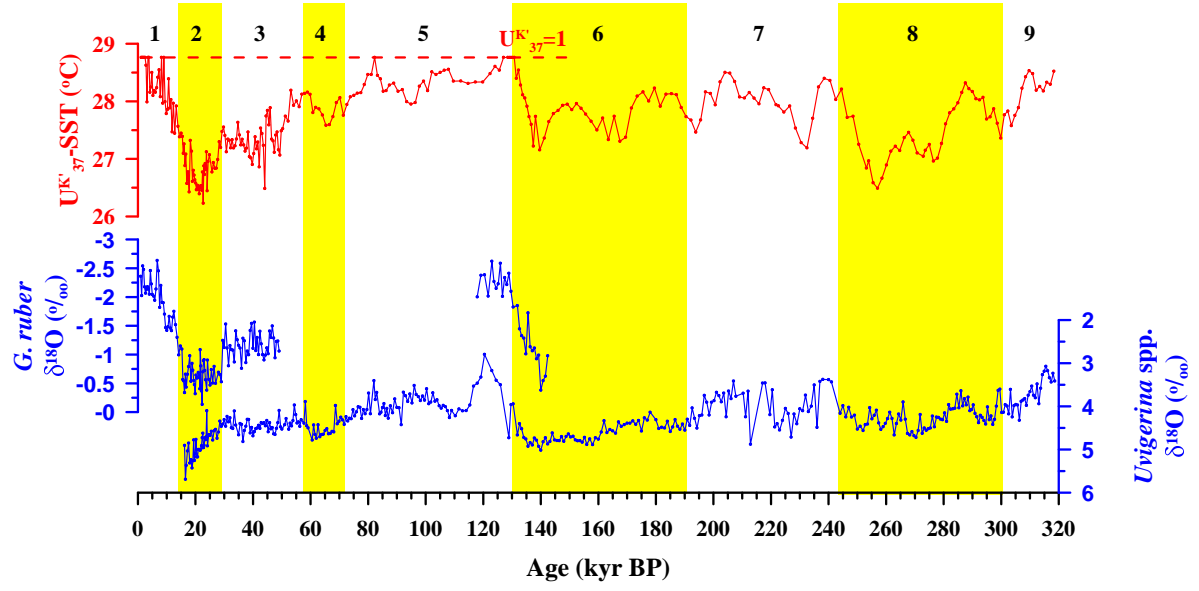

Fig. 2. Downcore variations of $U_{37}^{K^{\prime}}$-SST, planktic and benthic oxygen isotope data of core MD052928. The red dash indicates the $U_{37}^{K^{\prime}}=1$ means the $C_{37: 3}$ alkenone is under the detectable.
CPD

10, 1857-1899, 2014

Implication on tropical climate dynamics

L.-J. Shiau et al.

\section{Title Page}

\section{Abstract}

Introduction

Conclusions

References

Tables

Figures

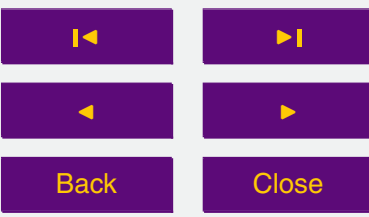

Full Screen / Esc

Printer-friendly Version

Interactive Discussion 


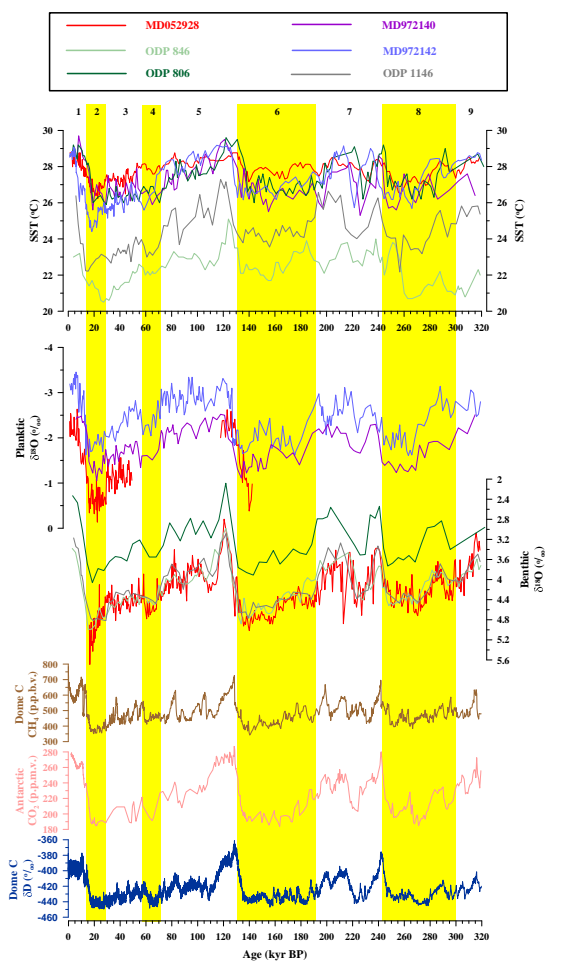

CPD

10, 1857-1899, 2014

Implication on

tropical climate

dynamics

L.-J. Shiau et al.

Title Page

Abstract

Introduction

Conclusions

References

Tables

Figures

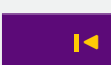

14

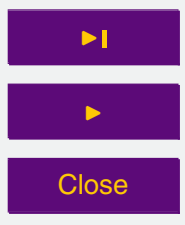

Back

Close

Full Screen / Esc methane $\left(\mathrm{CH}_{4}\right)$, carbon dioxide $\left(\mathrm{CO}_{2}\right)$ concentrations and $\delta D$ recorded in the Antarctic ice core. The age model of all three ice core records is based on the EDC3 age model (Parrenin et al., 2007). The planktic oxygen isotope records of MD972142, MD972140 and MD052928 are all based on $G$. ruber. The benthic oxygen isotope records are based on: MD052928: Uvigerina spp.; ODP806: Cibicidoides wuellerstorfi (Bickert et al., 1993); ODP846: C. wuellerstorfi or Uvigerina Peregrina (Mix et al., 1995); ODP 1146: Cibicidoides spp. or Uvigerina spp. (Clemens et al., 2008).

Printer-friendly Version

Interactive Discussion 
CPD

10, 1857-1899, 2014

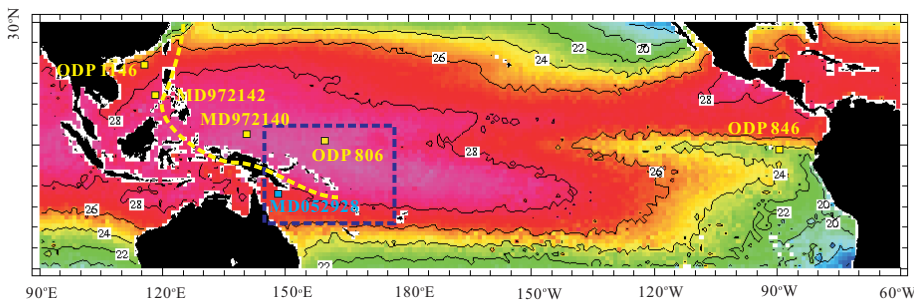

(b)
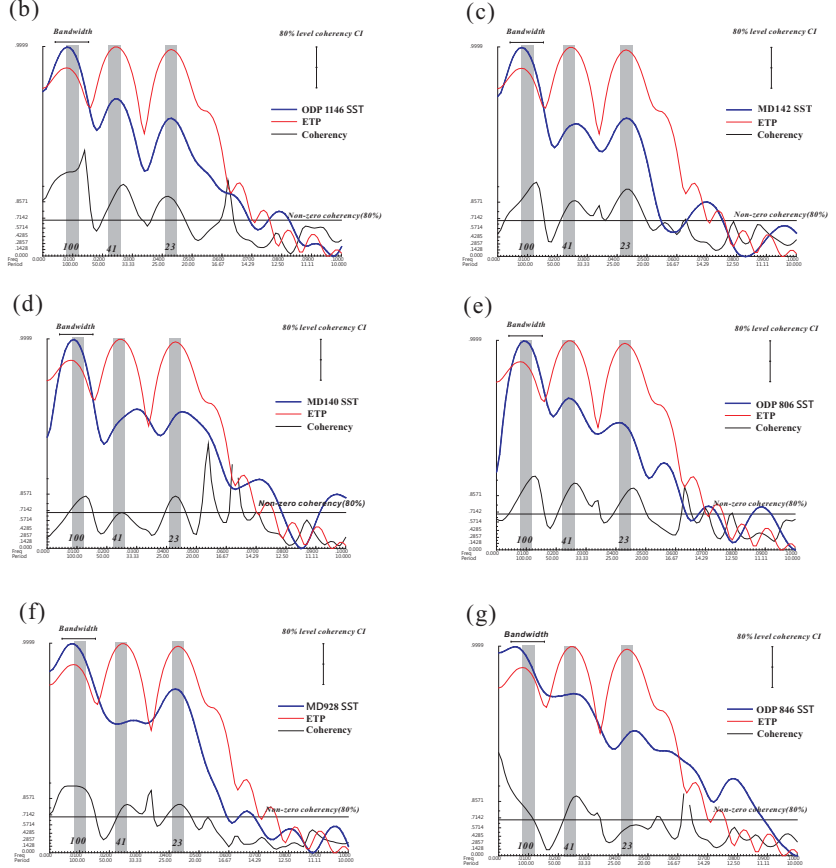

Implication on tropical climate dynamics

L.-J. Shiau et al.

Title Page

Abstract

Introduction

Conclusions

References

Tables

Figures

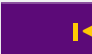

14

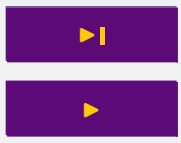

Back

Close

Full Screen / Esc

Printer-friendly Version

Interactive Discussion

(ㄷ) (1) 
Fig. 4. (a) The geographic distribution of cross-spectral results of SST relative to ETP; The power density and coherency: (b) ODP 1146; (c) MD972142; (d) MD972140; (e) ODP 806; (f) MD052928; (g) ODP 846. Arand program (Howell et al., 2006) is used to calculate the crossspectra, the parameters: lags $=120$, Bandwidth $=0.011, \Delta t=1 \mathrm{kyr}$. In (a), the yellow dash line indicates the boundary of early and late SST groups at obliquity and eccentricity bands; the early group at the precession band is encompassed by the deep blue dash rectangle.

\section{CPD}

10, 1857-1899, 2014

Implication on

tropical climate dynamics

L.-J. Shiau et al.

\section{Title Page}

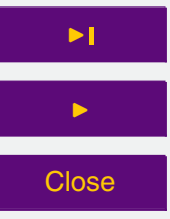

\section{Full Screen / Esc}

Printer-friendly Version

Interactive Discussion 
(a)

$$
O_{\max }
$$

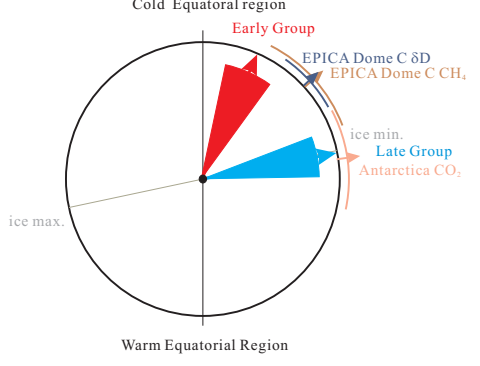

(c)

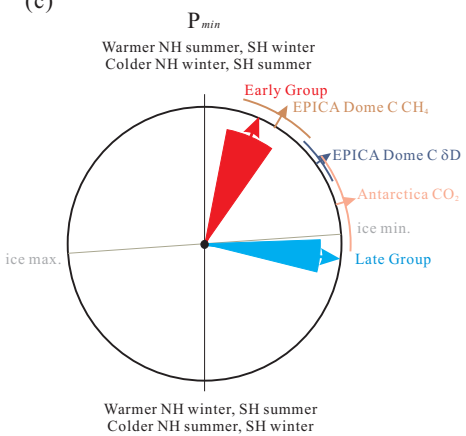

(b)
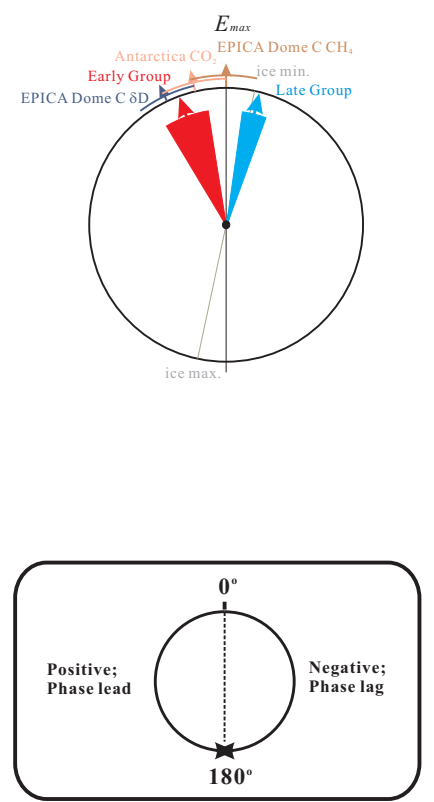

CPD

10, 1857-1899, 2014

Implication on tropical climate dynamics

L.-J. Shiau et al.

\section{Title Page}

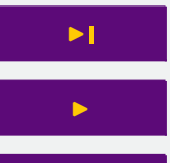

\section{Full Screen / Esc}

Printer-friendly Version

Interactive Discussion 


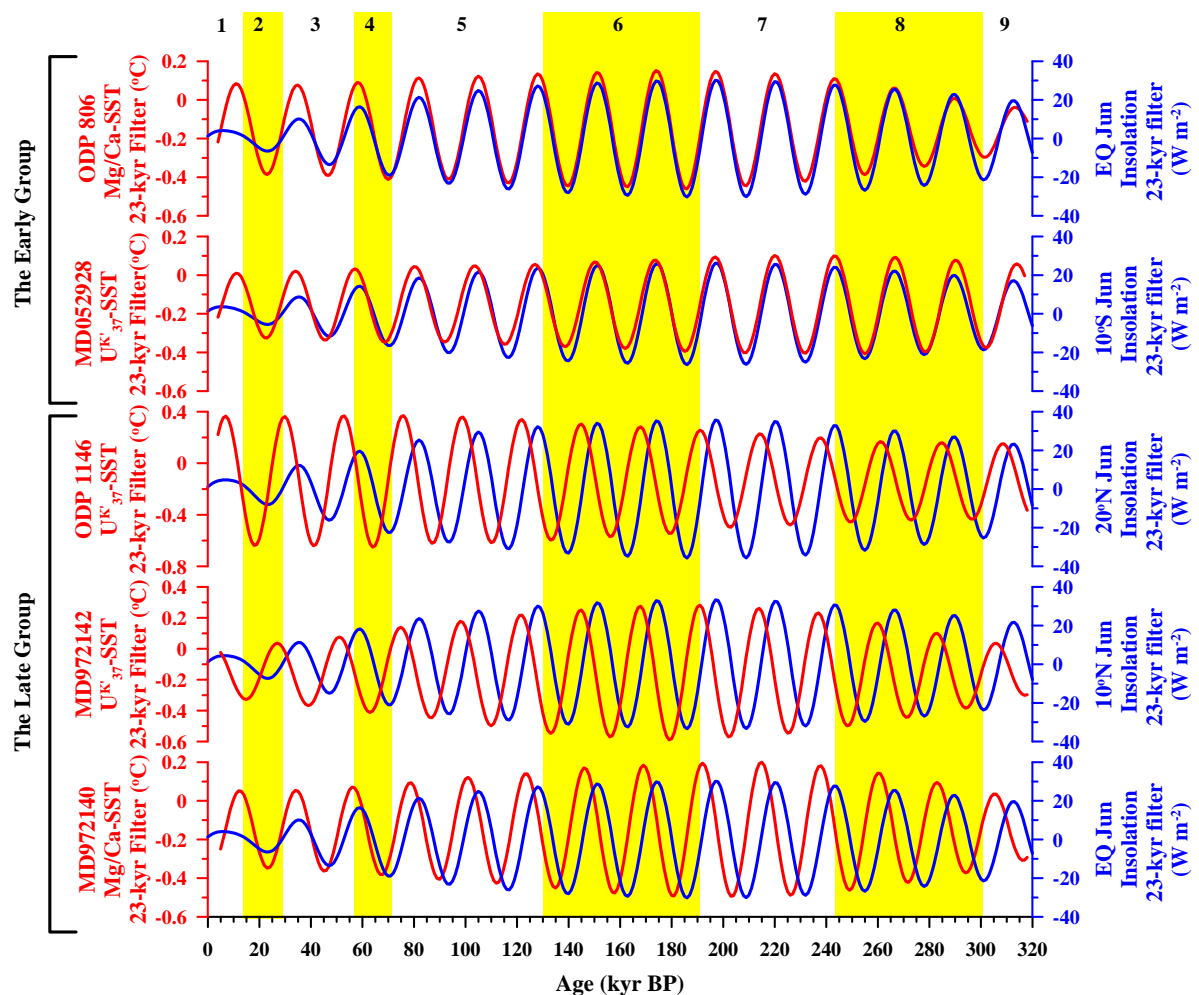

Fig. 6. Comparison of tropical Pacific SSTs and local insolation in June (Laskar, 1990) at the precession band. Red lines indicate the SSTs, and blue lines indicate the location insolations. The early group shows the SST and local insolation is phase significantly; however, the late group indicates the SST lags to the local insolation. In this Fig. we have correlated the phase differences as shown in Fig. S6c and Table S1.
CPD

10, 1857-1899, 2014

\section{Implication on tropical climate dynamics}

L.-J. Shiau et al.

\section{Title Page}

\section{Full Screen / Esc}

Printer-friendly Version

Interactive Discussion 


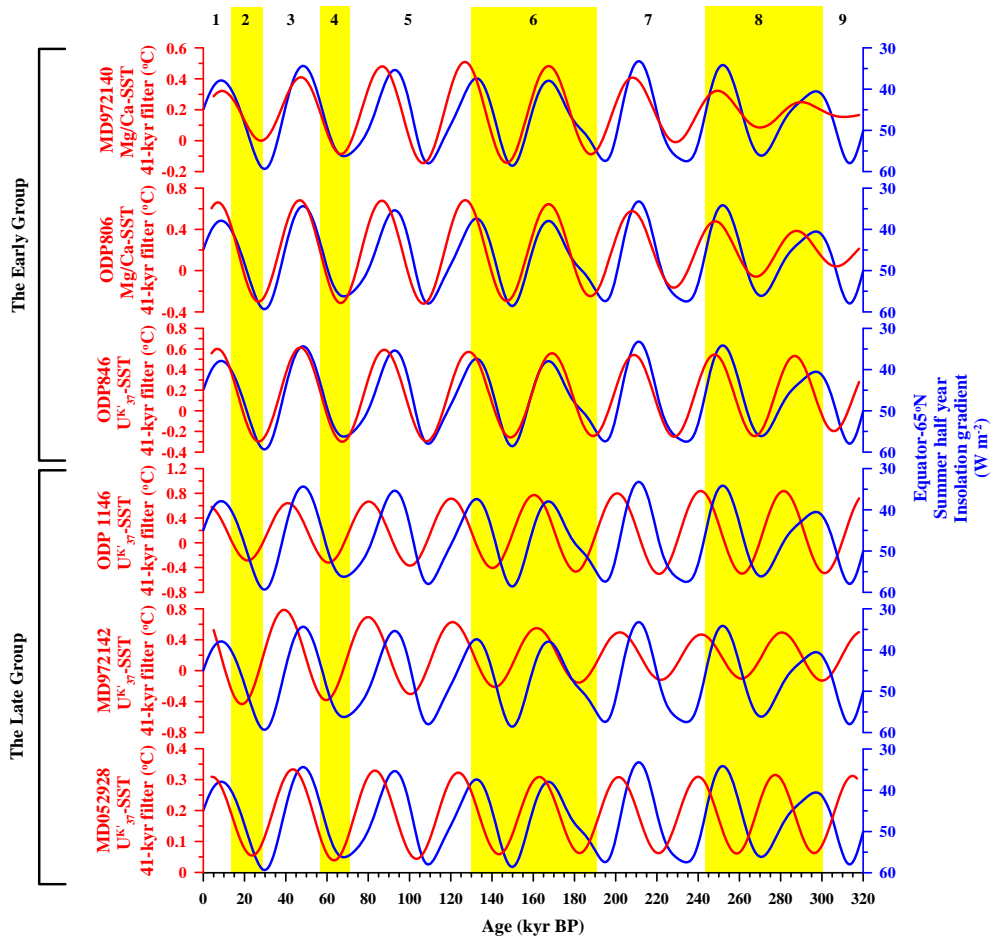

Fig. 7. Comparison of the 41-kyr component of tropical Pacific SSTs and the summer halfyear (21 March to 21 September) mean insolation (Laskar, 1990) gradient between the equator and $65^{\circ} \mathrm{N}$. Red lines indicate the SSTs, and Blue lines indicate the insolation gradient. The early group indicates the SST is associated to the insolation gradient; the late group indicates the SST response lags to the insolation gradient. In this Fig. the phase differences have been correlated as shown in Fig. S6a and Table S1.

\section{CPD}

10, 1857-1899, 2014

\section{Implication on tropical climate dynamics}

L.-J. Shiau et al.

\section{Title Page}
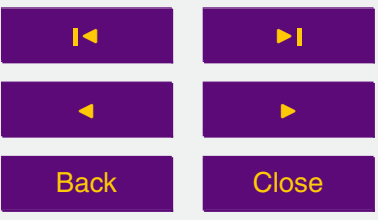

Back

Close

\section{Full Screen / Esc}

Printer-friendly Version

Interactive Discussion 